\title{
Delineation of Groundwater Potential Zone Through Geospatial Technique, Multi-Criteria Decision Analysis, And Analytical Hierarchy Process
}

Sunil Kumar Srivastava ( $\square$ sunil16sster@gmail.com )

Jaypee University of Engineering and Technology https://orcid.org/0000-0003-0357-4387

\section{Research Article}

Keywords: Groundwater Potential (GWP), Multi-Criteria Decision Analysis (MCDA), Analytical Hierarchy Process (AHP), Geospatial Technique, Receiver Operating Characteristic curve (ROC)

Posted Date: May 4th, 2021

DOI: https://doi.org/10.21203/rs.3.rs-419796/v1

License: (c) (i) This work is licensed under a Creative Commons Attribution 4.0 International License. Read Full License 


\section{Abstract}

Study Region: This study area is located in a subtropical semi-arid climatic zone of India, suffering due to the low availability of water. Hence, delineation of the groundwater potential zone (GWPZ) had performed through the geospatial technique, the multicriteria decision analysis (MCDA), and the analytical hierarchy process (AHP).

Study Focus: The thematic-layers of the geology, geomorphology, soil types, lineament-density, the slope of the topography, drainage-density, landuse, and land-cover developed and created by utilizing available supplementary data and digital satellite images. GWPZ had classified into 5 classes like excellent, good, moderate, poor, and very-poor. The summary of the methodology adopted for the delineation of GWPZ has given in fig2.

New Hydrological Insights for the Region: It had observed that the consistency index (Cl) was 0.0106 , while the random index (RI) for 7 variables considered from standard tables is 1.32 . The calculated consistency ratio (CR) in this study was 0.0080 lower than 0.1000 . This low CR indicated moderate consistency in the results of pairwise comparisons among the thematic layers assigned weight for analysis. Hence, the AHP model used for this research work has shown reasonably good accuracy. The statistics of GWPZ indicated $~ 3.97 \%$ of study-area possessed excellent GWPZ, $\sim 37.09 \%$ very-good, $\sim 41.72 \%$ moderate, $\sim 15.23 \%$ poor, and $\sim 1.99 \%$ very-poor. This model of the GWP map shows that the Area Under the Curve (AUC) of the Receiver Operating Characteristic Curve (ROC) is $\sim 0.726$. It indicated good agreement between experimental results and predicted results.

\section{Introduction}

Groundwater is one of the significant sources of freshwater in comparison to other freshwater sources available on the earth's surface (Senanayake et al. 2016; Shiklomanov 1993). The demand for freshwater has been increased significantly in the last few decades due to population growth, rapid urbanization, and industrialization. The availability of the groundwater in the specific geographical areas depends on the geology, lithology, topography, fractures, porosity, slope, lineament-density, drainage pattern, precipitation, climatic condition, types of land-use, and land-cover (Mukherjee et al. 2012; Srivastava and Ramanathan 2008; Singh et al. 2011). The availability of freshwater also varies with the change in seasons in this subtropical climatic zone, which possesses most of the precipitation in months (June to September) only through the monsoon. Approximately $10 \%$ of the available freshwater gets contaminated due to leaching of contaminants from the point and nonpoint source, mismanagement of the water resource, etc. Thus, the demands of the available freshwater have been increasing day by day worldwide in the last few decades. It was observed that the groundwater table depleted due to the high rate of withdrawal in comparison to the recharge rate.

Surface and subsurface water is used preferably as a freshwater source in this semi-arid study-area. Groundwater is the more precious comparison to surface water and broadly utilized for various purposes like irrigation, domestic, and commercial requirements. Surface water is available in small proportions through the seasonal rivers for a certain period only. Hence, groundwater importance has increased in this region as a source of fresh water. The study-area reported a sharp decline in groundwater table due to the excess withdrawal of sub-surface water in various proportions for irrigation, industrial consumption, and domestic requirement (Srivastava and Ramanathan 2018a). The scientific communities suggested that the decrease in groundwater table in wells, streams, and lakes caused the significant decline of the water quality, land subsidence, and increased groundwater pumping costs (Wada et al. 2010).

The scarcity of water and overexploitation of available subsurface water has created concern in scientific communities. It further motivates us to evaluate the Groundwater Potential (GWP) status in this subtropical climatic zone of India. The assessment of GWP is always a challenging task in comparison to surface water (Todd 1980; Ranjan et al. 2017). The subsurface water generally occurs in the weathered, fractured hard-rock aquifer, whose thickness depends on the geological formation and geography of the study area. The GWP zones are a type of water-bearing natural cavity of the earth's crust that acts like channels for transmission and also a reservoir for the storage of subsurface water.

The satellite image helped extensively in the identification and evaluation of the GWP zones in a geographical area due to its skill to recognize largeground landscapes easily (Prasad et al. 2006; Adamala et al. 2016). Further, it observed that simulation of various technologies, including Remote Sensing (RS) and Geographical Information System (GIS) for the exploration of the GWP zone, enhanced its ability of predictability (Murasingh et al. 2018). It observed that the researchers used RS and GIS in the demarcation of the GWP zone assessments in their respective study-area located in various geographical and climatic zones of the world (Andualem and Demeke 2019; Murasingh et al. 2018, 2013; Vijith 2007; Magesh et al. 2012; Biswas et al. 2012). The thematic-layers were prepared and utilized during the assessment of the GWP in this research work. In the study area, most of the regions were suffering from water scarcity due to poor geological conditions and unplanned extraction of groundwater for agriculture activity (Srivastava and Ramanathan 2018a). Hence, it is essential to explain the GWP zone in the study-area to optimize the utilization of groundwater for sustainable development. The traditional groundwater recharge potential was assessed through hydrological field investigations and modeling with a soil moisture model (Singh et al. 2019; Thorpe and Scott 1999; White et al. 2003). It had observed that in-situ investigation is costly, timeconsuming, difficult at a large scale in comparison to assessment through RS and GIS (Thapa et al. 2018; Srivastava and Ramanathan 2018b).

In this research work, the delineation of the GWP and distributions of subsurface water resources had performed by using RS and GIS data. The RS and GIS technique provides a synoptic view of a large-region. It simplified the evaluation process through improved and faster assessment and 
progress in groundwater management with collateral information. All these studies had based on an indirect calculation through topographical features, lineament density, drainage density, geomorphology, land-use/land-cover, slope, and hydrological characteristics of the study area.

The integrated approach of the RS, GIS, MCDA, and AHP had utilized in this research work for the evaluation and identification of suitable GWP zones and favorable artificial recharge zone in the Guna district. The researchers appreciated this technique and utilized RS, GIS, MCDA, AHP as tools for water resource management and other environmental management (Machiwal et al. 2011; Pourghasemi et al. 2012; Chandio et al., 2013; Althuwaynee et al. 2014). Few scientists also reported that GIS-MCDA could be convenient in delineating the active groundwater recharge zone in similar types of the study-area (Jha et al. 2014; Chowdhury et al. 2010). The scientists have utilized the AHP technique for calculating the significance of the geospatial thematic maps (Hajkowicz and Higgins 2008; Murthy and Mamo 2009; Hajkowicz and Collins 2007). The identification of a suitable groundwater recharge zone is an essential pre-requisite for the sustainable management of groundwater resources. Groundwater recharge is a process of water infiltration from the unsaturated zones into the saturated zones (Freeze and Cherry 1979; Srivastava 2019). It occurred only in the conditions when the water has flown underneath the ground and infiltrates into the saturated zone (Yeh et al. 2016).

This research work aims to develop the thematic-layers of the GWP zones and the identification of suitable GWP zones in the Guna district. This study also identified and delineated the groundwater recharge zones through the integration of various modified and developed thematic-layers for the Guna district.

\section{Study-area}

This study-area has placed in the Madhya Pradesh state of India, geographically located in the NE of the Malwa Plateau between the Parbati River

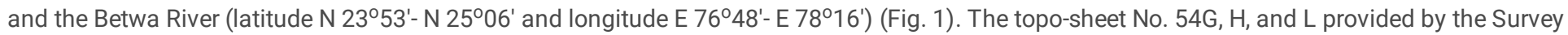
of India (SOI) was utilized for the development of the study area map. The study-area inhabited by $\sim 1260$ villages, resided $\sim 13$ million peoples as per the Census of Government of India (2011). Almost all peoples are living in the villages and fully dependent on the subsurface water for irrigation, domestic and commercial requirements. The annual rainfall was $\sim 108.72 \mathrm{~cm}$ and received maximum rainfall ( $\sim 86 \%)$ through SW monsoon (from June to September). The atmospheric temperature ranged from $4.8^{\circ} \mathrm{C}$ (in winter) to $46^{\circ} \mathrm{C}$ (in summer) as per the Indian Meteorological Department (IMD) report (2011-2020).

\section{Methodology}

This study was performed with well-planned and adopted an integrated approach methodology, which included the collection of data, analysis, interpretation, and validation of results. The geospatial technique, MCDA, and AHP were utilized in this research work to delineate the GWP of the study-area. Seven thematic-layer had used in this research work for the delineating GWP zone through MCDA and AHP methods. The summary of the methodologies adopted for the delineations of GWP zones has given in Fig. 2.

At the initial stage published maps, remote sensing data, and groundwater data has collected through various Government of India agencies. These agencies are the Central Pollution Control Board (CPCB), Madhya Pradesh Pollution Control Board (MPCB), Survey of India (SOI), Madhya Pradesh Council of Science and Technology (MPCST), IRS Bhuwan portal, etc. The groundwater water-table data was collected in-situ during field observation through pumping test by using monitoring wells identified within the study area. The remote sensing data had collected for image enhancement and classification through ArcGIS software.

The thematic map was developed by using the published-map (after digitization and rectifications), remote sensing data, and monitoring well data. The published-map that utilized during the delineation of GWP are hydrogeology, soil texture, lineament density, drainage density, land-use, and slope of the topography. The MCDA had utilized in this research for assigning the weightage to all variables used during calculations. Ranking of themes and AHP has used during the evaluation of the normalized weight of individual theme and their diverse layers. The methodology suggested by Saaty (1990) had used in this research work for the calculation of the consistency ratio (CR) and the consistency index (CI).

The statistical calculation has performed during the assessment of the groundwater potential index (GWPI) and further these data were used for the delineation GWP zone in the project study area. The validation of the GWP map has performed by using primary data collected from the field through the pumping test. The Receiver Operating Characteristic Curve (ROC) and the Area Under the Curve (AUC) have developed during the validation of the GWP map of the study area.

\section{Result And Discussions}

\section{1 Development of Thematic Maps}

The development of the thematic maps is a primary step for the delineation and identification of the suitable GWP zone in the projected study-area. These maps were collected for the development of thematic maps through various sources like IRS-Bhuwan, India, CPCB, MPCB, literature, and annual reports of MPCST, Bhopal, etc. The land-cover thematic-map has also been formulated by categorizing the satellite image and validating it 
with actual information or experimental data available on the ground. The software available for the development of thematic maps had utilized in this research work.

\subsubsection{Geology}

Vindhyan sandstone, shales, and limestone were available in surplus proportions in the geology of the study area. The natural aquifer identified within the weathered fractured jointed Deccan-traps, the shale, and the Vindhyan sandstone (CGWB, 2013-20). Around 66\% portion of the study-area possessed Deccan-trap basalt of the Malawa Group, which indicated a long-period of geological developments (Fig. 3). The statistics of the geology of the study-area have shown in table 1. The statistical assessment of the lithology of the study area indicated that the Deccan-trap occupied $~$ $4830.4 \mathrm{~km}^{2}(\sim 74.49 \%)$ of the study area (Table 1$)$. Laterite dominating lithology occupied $\sim 55.12 \mathrm{~km}^{2}(\sim 0.85 \%)$ of the study area. Vindhyan sandstone and the shale dominating geology distributed in $\sim 1538.15 \mathrm{~km}^{2}(\sim 23.72 \%)$ of the study area. The geology of the study-area indicated $\sim$ $60.96 \mathrm{~km}^{2}(\sim 0.94 \%)$ of the study area (Table 1$)$.

Table 1 Geology

\begin{tabular}{|llll|}
\hline Sr. No. & Lithology type & Area $\left(\mathrm{km}^{2}\right)$ & Percentage (\%) \\
\hline 1 & Deccan-trap & 4830.40 & 74.49 \\
\hline 2 & Laterite & 55.12 & 0.85 \\
\hline 3 & Vindhyan Sandstone Shale & 1538.15 & 23.72 \\
\hline 4 & Limestone & 60.96 & 0.94 \\
\hline
\end{tabular}

The basaltic lawa flow caused the development of the Deccan-trap. These are mainly responsible for variations in the water holding capacities of the groundwater aquifers. The phreatic aquifer formed in these weathered, jointed, and fractured basalts. While in a few-region the basaltic layer was widespread and caused the development of large aquifer. The poor-permeability of this weathered basalt has resulted in these aquifers sustain only partial water withdrawals (Srivastava 2019). The north region possessed laterite of the Cainozoic age. These were ferruginous in characteristics with a thickness of 1-5 m. Alluvium-dominated thin strip observed with flood-plain of the seasonal river in the region. It's composed of gravels, silt, pebble-beds, and sands. The granular portion of this geological development has created a good-aquifer with low thickness. The water-table below ground level has ranged between 3.80-18.94 m in the pre-monsoon (May and June) and 1.54-6.50 $\mathrm{m}$ in post-monsoon (September to October). Lamata Group (composed of siliceous limestone and highly fossiliferous sandstone) and the Vindhyan formations have occupied a very-small area. The northern part, around 8-25 km SW of the Sirsi was exposed to Lamata Group, horizontally aligned below the Deccan-trap formations (CGWB 2013-20).

Subsurface water occurred under the phreatic condition with significant yields. Bamori and Guna blocks exposed with the Vindhyan sandstone, which has been inserted with shale. Srivastava and Ramanathan (2018a) reported in their study that hard-rock was cracked and inter-connected at a different depth, further developed, and adopted it as a potential aquifer at a deeper level. The peoples are extracting surface water through a motorpump to fulfill the water requirement for irrigation, industrial and domestic. The field observation showed that the yield of bore-wells in the studyarea ranged between 2-10 liters/second. The unit-draft ranged from $0.005-0.017 \mathrm{mcm} /$ year in case of tube-wells and $0.001-0.008 \mathrm{mcm} / \mathrm{year}$ observed in the case of dug-wells (CGWB 2013-20).

\subsubsection{Geomorphology}

Geomorphology showed the EW alignment of the Vindhyan-range possess the Sindh-valley, Malwa-plateau, and the Parbati river-valley. Binaganj and the Chachoda hills occupied the rest of the study area. The study of physiography indicated that it possessed the low-level plateau, flood-plains through the river, and the plain of extrusive origin with rocky-bench. The rest of the landforms was a low structural plateau, a plain of the Proterozoic rocks. The field study indicated the elevations ranged between $324-561 \mathrm{~m}$. The projected area in this research work falls under the Yamuna riverdrainage system supported with few seasonal rivers. The Parbati River and Kumo River are tributaries of the Chambal River drain that occupied most of the Guna district. The Eastern zone of the study-area drained through the Sindh River, and the flow direction of the river is towards the north with a low-gradient.

It possessed $\sim 15.55 \%$ forest and $\sim 50.68 \%$ sown-area. Approximately $62.25 \%$ of the study-area was arable land (CGWB 2013-20). It reported that $66.02 \%$ area under agricultural-activities created stress over subsurface water due to over-exploitation of groundwater for irrigation, the domestic and industrial requirement (Srivastava 2019). The study-area was also suffering from poor-quality and scarcity of water because these regions possessed fractured hard-rock aquifer, and further over-exploitation of subsurface water created anxiety over groundwater.

\subsubsection{Topography and Slope}

The topography of the study-area was varying significantly and also influenced the rate of recharge of the aquifer (Fig. 4). Those regions of the study-area have possessed a low slope (or plain-area) exposed to the possibility of high recharge in aquifers due to high residence times. While those areas have possessed a high-slope reduced the chance of recharge due to high surface runoff. In the study-area, the slope was ranging 
between 1-35\% (Table 2). The statistics indicated that $\sim 5506.10 \mathrm{~km}^{2}(\sim 84.91 \%)$ of study-area possessed slope in between 0-1\%; 383.89 $\mathrm{km}{ }^{2}(\sim$ $5.92 \%)$ of study-area possessed $1-3 \%$ slope; $\sim 267.82 \mathrm{~km}^{2}(\sim 4.13 \%)$ of study-area possessed 3-5\% slope; $171.84 \mathrm{~km}{ }^{2}(\sim 2.65 \%)$ of study-area possessed slope in between $5-10 \% ; ~ 103.75 \mathrm{~km}^{2}(\sim 1.60 \%)$ of study-area possessed slope in between 10-15\% and $\sim 51.23 \mathrm{~km}{ }^{2}(\sim 0.79 \%)$ of study-area possessed slope between 15-35\% (Table 2). The slope of the topography in the projected study-area has given in Fig. 4.

Table 2 Slope

\begin{tabular}{|llll|}
\hline Sr. No. & Slope (\%) & Area $\left(\mathrm{km}^{2}\right)$ & Percentage (\%) \\
\hline 1 & $0-1 \%$ & 5506.10 & 84.91 \\
\hline 2 & $1-3 \%$ & 383.89 & 5.92 \\
\hline 3 & $3-5 \%$ & 267.82 & 4.13 \\
\hline 4 & $5-10 \%$ & 171.84 & 2.65 \\
\hline 5 & $10-15 \%$ & 103.75 & 1.6 \\
\hline 6 & $15-35 \%$ & 51.23 & 0.79 \\
\hline
\end{tabular}

The characteristics of land-use also depend on the slope of topography because it influenced the residence time of water. Hence the slope of topography influenced the growth of vegetation, the density of the forest, agriculture activities, and the nature of the soil. Agricultural activities have affected them directly and indirectly. Agriculture activities were better in plain-area in comparison to high slope topography. Hence, the slope of topography helped in pedological development, climatic modification, level of groundwater-table, development and enrichment of the soil, air drainage, etc.

The high slope of topography has also increased the soil weathering and caused the loss of fertility of the soil. While, the plain regions (low slope topography) comparatively had improved the possibility of water holding capacity, recharge of the aquifer, development of the soils, upgradation of water-table, etc. The spatial distribution of the slope percentage of topography in the study area has shown in Fig. 4. It had observed that the projected study area possessed a moderate inclination of topography towards the north direction.

\subsubsection{Soils}

The soil of the study area had divided into three major types. The first classification indicated clay-rich soils mixed with small size stone, obtained in low depth. This type of clay-rich soil had observed in the zone that possesses low-plateau in the study area. The formation or development of such soils has occurred in the well-drained zone possessing heavy erosions. In the second classification obtained loamy soil in the well-drained zones that were possessed a moderate slope of topography within the study area. Such types of soils were also observed at a low depth and formed in those areas possessing intense erosion. The third category of fine soils had observed in moderate deep to deep-depth. It had developed through natural weathering in that topography possessed a gentle slope and shown a good drain area (Fig. 5).

The statistics on the soil types of the study-area have summarized in table 3. Approximately $915.63 \mathrm{~km}^{2}(\sim 14.12 \%)$ of study-area possessed the clay-rich soil, $\sim 211.40 \mathrm{~km}^{2}(\sim 3.26 \%)$ of study-area possess clay-skeletal soil, $\sim 505.15 \mathrm{~km}^{2}(\sim 7.79 \%)$ study-area dominated with coarse-loamy type soil; $\sim 1654.23 \mathrm{~km}^{2}(\sim 25.51 \%)$ of study-area possessed fine soil; $\sim 219.83 \mathrm{~km}^{2}(\sim 3.39 \%)$ of the study-area mixed with fine-loamy soils; $\sim 139.42 \mathrm{~km}^{2}$ ( 2.15\%) of study-area having fine-silt soil; $\sim 2719.65 \mathrm{~km}^{2}$ ( 41.94\%) of study-area dominated with loamy soil; $77.17 \mathrm{~km}{ }^{2}(\sim 1.19 \%)$ of study-area possessed the loamy-skeletal soil and $\sim 42.15 \mathrm{~km}^{2}(\sim 0.65 \%)$ of study-area possessed the other types of soil (Table 3 ). The map of the soil distribution in the study-area has given in Fig. 5 .

Table 3 Soil 


\begin{tabular}{|llll|}
\hline Sr. No. & Soil Type & Area $\left(\mathrm{km}^{2}\right)$ & Percentage (\%) \\
\hline 1 & Clayey & 915.63 & 14.12 \\
\hline 2 & Clayey-skeletal & 211.40 & 3.26 \\
\hline 3 & Coarse-loamy & 505.15 & 7.79 \\
\hline 4 & Fine & 1654.23 & 25.51 \\
\hline 5 & Fine-loamy & 219.83 & 3.39 \\
\hline 6 & Fine-silty & 139.42 & 2.15 \\
\hline 7 & Loamy & 2719.65 & 41.94 \\
\hline 8 & Loamy-skeletal & 77.17 & 1.19 \\
\hline 9 & Other Soil & 42.15 & 0.65 \\
\hline
\end{tabular}

\subsubsection{Land-use and Land-cover}

Land-use and the land-cover maps were utilized in this research work, collected from the Indian Satellite image available at the IRS-BHUWAN website. The study area was classified into various segments of the land-use and land-cover as shown in Fig. 6 . This land-use and land-cover map included agricultural land, forest, grassland, waste or bare land, water bodies or wetland, and built-up area. A major portion of the study area had covered with dense forest and agricultural land extensively used for cultivating crops during agriculture activity. Few areas were non-fertile land due to the poor quality of soil and the poor availability of irrigation water. Considering the population load of the Guna district and also low availability of irrigation water created concerns in society and the scientific community. This motivated the study of delineation of the GWP zone through geospatial technique, MCDA, and AHP.

It is one of the important parameters which influenced the existence and development of the GWP zone. The existence of forest, grassland, agricultural land, waste-land, water bodies, built-up area, and wetland influenced the rate of surface runoff and infiltration differently. Hence, the availability of these factors in various proportions in the study-area also influenced the capacity of the developed GWP zone in the selected area. It was observed that forest cover, grassland, wetland, and flood plain area increased the infiltration rate and more favorable for the recharge of the groundwater aquifer. While the built-up area and barren land increased the surface runoff and showed poor infiltration rate and low recharge of aquifers. The only seasonal rivers like the Parbati River, the Kumo River, the Sindh River, and the Chaupat River drains the Guna district during the monsoon period. There were no perennial rivers had observed in the study area.

The land-use and land-cover map has shown a significant impact on the distribution of the GWP zone. The distribution of land-use and land-cover had also influenced by the characteristics of the soil and distributions of drainage of the available seasonal river. The summary of the statistics of land-use and land-cover has given in Table 4.

Table 4 Land-use and Land-cover

\subsubsection{Lineament-density}

\begin{tabular}{|llll|}
\hline Sr. No. & Land-use Type & Area $\left(\mathbf{k m}^{2}\right)$ & Percentage (\%) \\
\hline 1 & Agriculture land & 3986.2 & 61.47 \\
\hline 2 & Forest land & 1637.37 & 25.25 \\
\hline 3 & Wasteland or bare land & 509.05 & 7.85 \\
\hline 4 & Wetland or Water bodies & 123.19 & 1.90 \\
\hline 5 & Built-up area & 228.82 & 3.53 \\
\hline
\end{tabular}

The lineament-density of the study area had assessed by using the map, collected from the BHUWAN portal of the Indian Government (Fig. 7). The lineament-density of the study area was calculated in this research work by using the following formulae as suggested by various researchers worldwide (Yeh et al. 2016; Andualem and Demeke 2019).

$$
\text { Lineament-density }=\frac{\sum_{i=1}^{i=n} L i}{A}
$$

Where Li indicated the lineament length in the study-area and A is the unit area for the respective zone. 
The study-area had classified into three major ranges/classification of lineament-density. It observed that the lineament-density ranged between $0-$ $0.10 \mathrm{~km} / \mathrm{km}^{2}$ for $\sim 42.54 \%\left(\sim 2758.39 \mathrm{~km}^{2}\right)$ area of the district, lineament-density ranged between $0.10-0.20 \mathrm{~km} / \mathrm{km}^{2}$ for $\left.\sim 28.36 \%(\sim 1838.92 \mathrm{~km})^{2}\right)$ area of the district and $0.20-0.35 \mathrm{~km} / \mathrm{km}^{2}$ for $\sim 29.10 \%\left(1887.32 \mathrm{~km}^{2}\right)$ of total study-area of the district (Table 5). The high lineament-density increased the possibility of plum recharge of the groundwater aquifer and hence supports the better GWP zone. The study-area has a lineamentdensity between $0.20-0.35 \mathrm{~km} / \mathrm{km}^{2}$ was considered an excellent GWP zone, which enclosed $\sim 29.10 \%$ of the study area (Fig. 7).

Table 5 Lineament Density

\begin{tabular}{|llll|}
\hline Sr. No. & Lineament Density $\left(\mathbf{k m} / \mathbf{k m}^{2}\right)$ & Area $\left(\mathbf{k m}^{2}\right)$ & Percentage (\%) \\
\hline 1 & $0-0.10$ & 2758.39 & 42.54 \\
\hline 2 & $0.10-0.20$ & 1838.92 & 28.36 \\
\hline 3 & $0.20-0.35$ & 1887.32 & 29.10 \\
\hline
\end{tabular}

\subsubsection{Drainage-density}

The drainage map helped in the understanding of the actual information of lithology, hydrogeological features, and structural control of the landform evolution (Andualem and Demeke 2019; Mukherjee and Singh 2012). The drainage-density $\left(\mathrm{km} / \mathrm{km}^{2}\right)$ demonstrated the numerical calculation of the average length of a river network within the complete basin because, it expressed the nearness of the typography within the river network (Andualem and Demeke 2019). It has shown the just opposite of the penetrability of the groundwater and plays an essential part in the runoff dispersal and the level of penetration. The GWP was mostly poor in high drainage-density areas due to the loss of most of the rainwater through surface runoff and the least amount of rainwater available for infiltration and recharge of the aquifer. Hence, those areas possessing higher drainage-density had shown less recharge of the aquifer. The drainage-density map has shown in Fig. 8.

\subsubsection{Groundwater Level}

In this research work, the groundwater level map was borrowed from the Central Ground Water Board (CGWB). The groundwater level of the Guna district was regularly measured 4-times/year by the CGWB through 25 dug-well and 8 piezometers located in the district. The study of fluctuations of the groundwater level in pre-monsoon and post-monsoon helped to understand practical situations of the groundwater in the study area. The depth of the water table in pre-monsoon ranged from 2.95-17.4 m below the ground level (CGWB 2013-20). In pre-monsoon better situations were observed in Akoda village (water level $2.95 \mathrm{~m}$ ) located at latitude N 24区 51》 and longitude E 77ه 11区. While the poor situation of the water table in pre-monsoon was observed in village Myana (17.40 m) located at latitude N 24区 51》 and longitude E 77区 27区 (CGWB 2013-20).

In pre-monsoon, around $4.92 \%\left(\sim 319.04 \mathrm{~km}^{2}\right)$ area possessed the groundwater table at less than $4 \mathrm{~m}$ below the ground level. Similarly, around $22.87 \%\left(\sim 1483.04 \mathrm{~km}^{2}\right)$ area possessed groundwater table in between 4-8m below the ground level, around $27.45 \%\left(\sim 1780.03 \mathrm{~km}{ }^{2}\right)$ area showed the groundwater table in between $8-12 \mathrm{~m}$ below the ground level, around $36.42 \%\left(\sim 2361.70 \mathrm{~km}^{2}\right)$ area possessed groundwater table in between 12 $16 \mathrm{~m}$ below the ground level and only $8.34 \%\left(\sim 540.82 \mathrm{~km}^{2}\right)$ area possessed water table more than $16 \mathrm{~m}$ below the ground level.

In post-monsoon, the water levels ranged from $2.85-17.65 \mathrm{~m}$ below the ground level. The small variation in water level between pre-monsoon and post-monsoon due to the poor rate of recharge in the study area. The better groundwater recharge was observed in Berkheri (+ $0.50 \mathrm{~m})$, while poor recharge was observed in Myana (+ $0.15 \mathrm{~m})$. In post-monsoon, $\sim 27.89 \%$ area $\left(\sim 1808.56 \mathrm{~km}^{2}\right)$ possessed a groundwater table at less than $5 \mathrm{~m}$ below the ground level. Similarly, in post-monsoon, $\sim 52.29 \%\left(\sim 3390.81 \mathrm{~km}^{2}\right)$ area possessed groundwater table in between $5-10 \mathrm{~m}$ below the ground level, $\sim 13.89 \%\left(\sim 900.72 \mathrm{~km}^{2}\right)$ area showed the groundwater table in between $10-15 \mathrm{~m}$ below the ground level, and only $5.93 \%$ ( 384.54 $\mathrm{km}^{2}$ ) area possessed water table depth more than $15 \mathrm{~m}$ below the ground level.

Details of observation well and sampling well are given in Fig. 1 and Fig. 3. The secondary data also collected from the annual report of the CPCB, MPCB, and MPCST and effectively utilized during the validation model and predicted results. CGWB (2013-20) reported around 71020 ham net groundwater available in the district. The groundwater draft including all applications in the study-area was 40459 ham indicated 56.97\% development stage of groundwater. The study area is divided into the non-command zone ( 96.01\%) and command zone ( 3.99\%) as per the availability of the groundwater resource in the district.

4.2 Weight Assignment

\subsubsection{Multicriteria Decision Analysis (MCDA)}

MCDA was utilized in this research work to assign the relative weights to all variables. These variables are geology, the slope of topography, geomorphology, lineament-density, drainage-density, soil types, land-cover, and land-use, which were utilized during the GWP assessment in this research work (Table 6). The researchers have enlightened various mechanisms in weight assignment criteria for the GWP assessment in their respective research work worldwide (Andualem and Demeke 2019; Yeh et al. 2016; Nampak et al. 2014; Rajaveni et al. 2017; Ibrahim-Bathis and Ahmed 2016; Rahmati et al. 2015). In this research work, the weight assignment has been carried out based on the literature reviews and an 
understanding of the soil, geology, physiography, lineament-density, drainage-density, land-use, and land-cover in the study area. In this research work relative weight is assigned between 1 to 9 as explained under the Saaty's Scale (1990). The maximum weight has given 9 and suggests extreme importance, while weight assigned 1 for the least important accordingly. The details of pair-wise comparisons of the assigned weight of these variables thematic layers have given in table 7.

Table 6 Weight Assigned to variable

\begin{tabular}{|llll|}
\hline Sr. No. & Variables & Basis of Categorization & Assigned Weight \\
\hline 1 & Geology & Rock types, weathering character, joints, fracture, etc. & 7 \\
\hline 2 & Slope & Slope Percentage & 6 \\
\hline 3 & Geomorphology & Landform type & 5 \\
\hline 4 & Lineament density & Lineament density value & 4 \\
\hline 5 & Drainage Density & Drainage density value & 3.5 \\
\hline 6 & Land-cover & Land cover type, status and condition & 3 \\
\hline 7 & Soil type & Permeability, porosity, and texture & 2.5 \\
\hline
\end{tabular}

Table 7 Pair-wise comparison matrix

\begin{tabular}{|llllllllll}
\hline Variables & Geology & Slope & Geomorphology & $\begin{array}{l}\text { Lineament } \\
\text { Density }\end{array}$ & $\begin{array}{l}\text { Drainage } \\
\text { Density }\end{array}$ & $\begin{array}{l}\text { Land- } \\
\text { cover }\end{array}$ & $\begin{array}{c}\text { Soil } \\
\text { Geometric } \\
\text { mean }\end{array}$ & $\begin{array}{l}\text { Normalized } \\
\text { weight }\end{array}$ \\
\hline Geology & 1.0000 & 1.2727 & 1.4000 & 1.5556 & 1.7500 & 2.0000 & 3.5000 & 1.6546 & 0.2282 \\
\hline Slope & 0.7857 & 1.0000 & 1.1000 & 1.2222 & 1.3750 & 1.5714 & 2.7500 & 1.3001 & 0.1793 \\
\hline Geomorphology & 0.7143 & 0.9091 & 1.0000 & 1.1111 & 1.2500 & 1.4286 & 2.5000 & 1.1819 & 0.1630 \\
\hline $\begin{array}{l}\text { Lineament } \\
\text { Density }\end{array}$ & 0.6429 & 0.8182 & 0.9000 & 1.0000 & 1.1250 & 1.2857 & 2.2500 & 1.0637 \\
\hline $\begin{array}{l}\text { Drainage } \\
\text { Density }\end{array}$ & 0.5714 & 0.7273 & 0.8000 & 0.8889 & 1.0000 & 1.1429 & 2.0000 & 0.9455 \\
\hline Land-cover & 0.5000 & 0.6364 & 0.7000 & 0.7778 & 0.8750 & 1.0000 & 1.7500 & 0.1304 \\
\hline Soil & 0.2857 & 0.3636 & 0.4000 & 0.4444 & 0.5000 & 0.5714 & 1.0000 & 0.4727 \\
\hline Sum & $\mathbf{4 . 5 0}$ & $\mathbf{5 . 7 3}$ & $\mathbf{6 . 3 0 0 0}$ & $\mathbf{7 . 0 0 0 0}$ & $\mathbf{7 . 8 8}$ & $\mathbf{9 . 0 0}$ & $\mathbf{1 5 . 7 5 0 0} \mathbf{7 . 4 4 5 8}$ \\
\hline
\end{tabular}

\subsubsection{Analytical Hierarchy Process (AHP)}

AHP was utilized in this research work during the evaluation of the normalized weight of the individual themes and their diverse layers. In AHP each variable is divided into a set of criteria, and further criteria are divided into sub-criteria. It has organized in certain preference order, to perform pairwise comparisons to find the normalized weights. The comparisons between these thematic-layers adopted the similar methodology in this research work as suggested or adopted by the other researchers in their respective research work (Chowdhury et al. 2010; Ranjan et al. 2017; Sahoo et al. 2015; Andualem and Demeke 2019; Machiwal et al. 2011). The normalized weight for each variable is calculated by each variable in a row by variables in columns (Table 7). The details of pairwise comparison and further normalized weight as the AHP process has given in table 7. The consistency ratio (CR) had calculated in this research work with the help of the consistency index (Cl) and standard random index (RI) for all seven variables (Table 8). It had observed that the consistency index was around 0.0106 , while the RI for seven variables considered from standard tables is 1.32. The calculated CR for this study was around 0.0080 much lower than 0.1000 (Table 8 ). This low CR indicated moderate consistency in the results of the pair-wise comparisons among the thematic layer assigned weight analysis. Hence, the AHP model used for this research work has shown reasonably good accuracy in geospatial prediction of the GWP zone in this study.

Table 8 Calculation of the consistency of data 


\begin{tabular}{|c|c|c|c|c|c|c|c|c|c|c|}
\hline Variables & Geology & Slope & Geomorphology & $\begin{array}{l}\text { Lineament } \\
\text { Density }\end{array}$ & $\begin{array}{l}\text { Drainage } \\
\text { Density }\end{array}$ & $\begin{array}{l}\text { Land- } \\
\text { cover }\end{array}$ & Soil & $\begin{array}{l}\text { Weighted } \\
\text { sum } \\
\text { value }\end{array}$ & $\begin{array}{l}\text { Normalized } \\
\text { weight }\end{array}$ & $\begin{array}{l}\text { Ratio of } \\
\text { sum } \\
\text { value to } \\
\text { criteria } \\
\text { weight }\end{array}$ \\
\hline Geology & 0.2282 & 0.2282 & 0.2282 & 0.2282 & 0.2282 & 0.2282 & 0.2282 & 1.5974 & 0.2154 & 7.41648 \\
\hline Slope & 0.1793 & 0.1793 & 0.1793 & 0.1793 & 0.1793 & 0.1793 & 0.1793 & 1.2551 & 0.1692 & 7.41648 \\
\hline Geomorphology & 0.1630 & 0.1630 & 0.1630 & 0.1630 & 0.1630 & 0.1630 & 0.1630 & 1.1410 & 0.1538 & 7.41648 \\
\hline $\begin{array}{l}\text { Lineament } \\
\text { Density }\end{array}$ & 0.1467 & 0.1467 & 0.1467 & 0.1467 & 0.1467 & 0.1467 & 0.1467 & 1.0269 & 0.1385 & 7.41648 \\
\hline $\begin{array}{l}\text { Drainage } \\
\text { Density }\end{array}$ & 0.1304 & 0.1304 & 0.1304 & 0.1304 & 0.1304 & 0.1304 & 0.1304 & 0.9128 & 0.1231 & 7.41648 \\
\hline Land-cover & 0.1141 & 0.1141 & 0.1141 & 0.1141 & 0.1141 & 0.1141 & 0.1141 & 0.7987 & 0.1077 & 7.41648 \\
\hline Soil & 0.0652 & 0.0652 & 0.0652 & 0.0652 & 0.0652 & 0.0652 & 0.0652 & 0.4564 & 0.0923 & 4.94432 \\
\hline Sum & 1.0269 & 1.0269 & 1.0269 & 1.0269 & 1.0269 & 1.0269 & 1.0269 & & 1.0000 & 49.4432 \\
\hline
\end{tabular}

$\lambda_{\max }=49.4432 / 7=7.063$

Consistency Index $(\mathrm{Cl})=0.01055$

Consistency Ratio $(\mathrm{CR})=\mathrm{Cl} / \mathrm{RI}=0.008$

Soil possessing poor-drainage property mostly observed high water holding or high water-storage capacity. While those soils having better drainage, property shows mostly poor water storage or poor-water holding capacity. Hence, clay textured vertisols soils available in the study-area $\sim 18 \%$ area was considered excellent for water storage prospects (Fig. 5). The details of normal weight and normalized weight for the various soils type have given in Table 9. 


\begin{tabular}{|c|c|c|c|c|}
\hline Theme & Features/Class & Assigned Weight & Geometric Mean & Normalized Weight \\
\hline \multirow[t]{4}{*}{ Geology } & Deccan-trap & 3 & 0.98 & 0.16 \\
\hline & Laterite & 6 & 1.70 & 0.28 \\
\hline & Vindhyan Sandstone Shale & 5 & 1.47 & 0.24 \\
\hline & Limestone & 7 & 1.93 & 0.32 \\
\hline \multirow[t]{6}{*}{ Slope (\%) } & $0-1 \%$ & 7 & 2.03 & 0.25 \\
\hline & $1-3 \%$ & 6 & 1.78 & 0.22 \\
\hline & $3-5 \%$ & 5 & 1.52 & 0.18 \\
\hline & $5-10 \%$ & 4 & 1.25 & 0.15 \\
\hline & $10-15 \%$ & 3 & 0.98 & 0.12 \\
\hline & $15-35 \%$ & 2 & 0.69 & 0.08 \\
\hline \multirow[t]{9}{*}{ Soil } & Clayey & 7 & 2.08 & 0.18 \\
\hline & Clayey-skeletal & 6.5 & 1.95 & 0.17 \\
\hline & Coarse-loamy & 6 & 1.81 & 0.16 \\
\hline & Fine & 5 & 1.54 & 0.14 \\
\hline & Fine-loamy & 4 & 1.26 & 0.11 \\
\hline & Fine-silty & 3 & 0.97 & 0.09 \\
\hline & Loamy & 2 & 0.67 & 0.06 \\
\hline & Loamy-skeletal & 2 & 0.67 & 0.06 \\
\hline & Other Soil & 1 & 0.36 & 0.03 \\
\hline \multirow[t]{5}{*}{ Land Use and Land Cover } & Agriculture land & 6 & 2.02 & 0.30 \\
\hline & Forest land & 7 & 2.31 & 0.34 \\
\hline & Wasteland or bare-land & 2 & 0.79 & 0.12 \\
\hline & Wetland or Water-bodies & 4 & 1.12 & 0.18 \\
\hline & Built-up area & 1 & 0.44 & 0.06 \\
\hline \multirow[t]{3}{*}{ Lineament Density } & $0-0.1$ & 5 & 1.24 & 0.29 \\
\hline & $0.1-0.2$ & 6 & 1.42 & 0.33 \\
\hline & $0.2-0.35$ & 7 & 1.60 & 0.37 \\
\hline \multirow[t]{5}{*}{ Drainage Density } & $0-0.25$ & 7 & 1.69 & 0.26 \\
\hline & $0.25-0.50$ & 6 & 1.49 & 0.23 \\
\hline & $0.50-0.75$ & 5 & 1.36 & 0.21 \\
\hline & $0.75-1.00$ & 4 & 1.06 & 0.16 \\
\hline & $1.0-1.92$ & 3 & 0.83 & 0.13 \\
\hline \multirow[t]{3}{*}{ Geomorphology } & Hill and mountain & 1.5 & 0.66 & 0.08 \\
\hline & Plain & 3 & 1.19 & 0.14 \\
\hline & Plateau & 2 & 0.84 & 0.10 \\
\hline
\end{tabular}




\begin{tabular}{|llll|}
\hline Valley & 4 & 1.52 & 0.19 \\
\hline Depression & 6 & 2.16 & 0.26 \\
Dissected Plain & 5 & 1.84 & 0.22 \\
\hline
\end{tabular}

The classification and weight assignment to the lithology of the study area had carried out with the help of various literature published by researchers worldwide (Andualem and Demeke 2019; Workineh et al. 2010). The sedimentary rock dominating lithology had given a higher weight, due to its wobbly and friable character. It supports the high infiltration ability of rainwater (or recharge of the aquifer through rainwater). Igneous and metamorphic rock dominating lithology having columnar, massive, and dense character, which are mainly responsible for the poor recharge of the aquifer through rainwater. It showed a poor GWP zone in these areas due to low recharge through rainwater (Table 10).

Table 10 The summary of GWP zone of the study area

\begin{tabular}{|lllll|}
\hline Sr. No. & GWPI & Groundwater Prospect & Area $\left(\mathbf{k m}^{2}\right)$ & Percentages (\%) \\
\hline 1 & $0.110-0.159$ & Very-Poor & 128.83 & 1.99 \\
\hline 2 & $0.160-0.189$ & Poor & 987.73 & 15.23 \\
\hline 3 & $0.190-0.219$ & Moderate & 2705.51 & 41.72 \\
\hline 4 & $0.220-0.249$ & Very-Good & 2404.90 & 37.09 \\
\hline 5 & $0.250-0.310$ & Excellent & 257.67 & 3.97 \\
\hline
\end{tabular}

It observed that the area having higher lineament-density generally characterized with the presence of higher recharge zone had given higher weightage (Andualem and Demeke 2019; Ranjan et al. 2017; Yeh et al. 2016; Nampak et al. 2014; Rajaveni et al. 2017; Mukherjee et al. 2012). While the zone having higher drainage had given low-weight due to the presence of a low recharge zone in this area. Similarly, the steep-slope topography zone has given low weight, and low-slope topography to the plain-areas had given higher weight due to the availability of surplus time for the recharge of the aquifer in the plain-areas.

4.3 Groundwater Potential (GWP) Map Development

The GWP map in this research work was created through the overlapping of the various variables thematic-layers. Groundwater potential index (GWPI) helped in classify the projected study-area into several GWP zones. GWPI was calculated by the weighted overlay analysis tool by using the following Malczewski (1999) equation.

Groundwater Potential Index (GWPI) $=\sum_{k=1}^{m} \sum_{\mathrm{i}=1}^{\mathrm{n}}(\mathrm{Wi} \times \mathrm{Wj})$

$=\frac{(\mathrm{Gi} \times \mathrm{Gj}+\mathrm{Si} \times \mathrm{Sj}+\mathrm{LDi} \times \mathrm{LDj}+\mathrm{DDi} \times \mathrm{DDj}+\mathrm{LCi} \times \mathrm{LCj}+\mathrm{STi} \times \mathrm{STj}+\mathrm{GMi} \times \mathrm{GMj})}{\sum \text { Total Weight }}$

Where Wi defined as the normalized weight of the $i^{\text {th }}$ thematic-layers and $W_{j}$ is defined as the normalized weight of the $j^{\text {th }}$ features of thematiclayers, $\mathrm{m}$ is the total number of thematic-layers, and $\mathrm{n}$ is the total number of features within a theme. The symbol $\mathrm{G}$ used for geology, $\mathrm{S}$ for soil, LD for lineament density, DD for drainage density, LC for land-cover and land-use, ST for the slope of topography, and GM used for the geomorphology of the study area.

The numerical value of GWPI utilized in this research work for the classification of the targeted area into the various category like Excellent, Good, Very good, Moderate, Poor, and Very Poor (Jha et al. 2014; Chowdhury et al. 2010; Sahoo et al. 2015). It is a dimensionless parameter that helped in indexing or categorizing the study-area into various GWP zone to fulfill the objective of this research work (Murasingh et al. 2017). The summary of the statistics of GWP of the study-area has given in Table 10. The statistics of GWP indicated $\sim 257.67 \mathrm{~km}^{2}(\sim 3.97 \%)$ of study-area possessed excellent GWP conditions, $\sim 2404.90 \mathrm{~km}^{2}$ area ( 37.09\% of total area) possessed very-good conditions, $\sim 2705.51 \mathrm{~km}{ }^{2}(\sim 41.72 \%)$ of study-area possessed moderate conditions, $\sim 987.73 \mathrm{~km}^{2}(\sim 15.23 \%)$ of study-area possessed poor conditions and $128.83 \mathrm{~km}{ }^{2}(\sim 1.99 \%)$ of study-area possessed very-poor condition (Table 10).

The spatial distribution of the GWP zone in the Guna district has given in Fig. 9. It indicated that the excellent condition of subsurface water observed in the northern part of the Guna district may be due to the dominance of forest and flat surface. This research work also supported by the report of CGWB (2016) shows 172.14 MCM water available in this zone of the Guna district is much higher than in another region. The stage of groundwater development in this region is around 51\%. (CGWB 2013-20) This area has also possessed a low population density and more forest area. While poor conditions had observed in the eastern and southeastern parts of the district may be due to poor-surface water recharge, high 
drainage, and excess water withdrawal. This region shows the poor condition of available water 104.93 MCM in comparison to another region of the Guna district. It also shows a poor-stage of groundwater development $\sim 36 \%$ only.

The surface plot and wireframe plot of the GWP has shown in Figs. 10a and b. The variations of GWP conditions have clearly shown in the threedimensional plot. The spatial distribution of the groundwater level of the Guna district has shown in Fig. 11. It indicated a large area of the Guna district possessed a water level below 30m depth on considering the geography of the study area. The statistics show $\sim 25.17 \%$ sample collected within 30m below the ground level, 30.46\% sample collected in between 30-60 m, 25.82\% sample collected in between 60-90 m, 5.96\% sample collected in between $90-120 \mathrm{~m}, \sim 8.60 \%$ sample collected in between $120-150 \mathrm{~m}$ and only $4.63 \%$ collected more than $150 \mathrm{~m}$ below the ground level.

\subsection{Validation of GWP Maps}

Groundwater potential map validation had been performed through primary data collected from the field through monitoring well located in the study-area by pumping tests. The existing water-tables map had also used along with data generated through pumping tests during the validation of prepared GWP models. The assessment of the performance of the validation of the GWP map carried out through the Receiver Operating Characteristic curve (ROC) and Area Under the Curve (AUC) in this research work (Naghibi et al. 2016).

The validation of the result had performed through correlating with the results obtained through the GWP map and experimental groundwater observations of the existing monitoring well. In this study likelihood ratio (LR) was also calculated for the quantitative assessment of GWP results with the help of the ROC curve and Bezier curve. The details of the Bezier curve, ROC curve, LR, and AUC has given in Fig. 12. It helped to validate the GWP model predicted results with the experimental value. The ROC curve and Bezier curve helped to calculate the LR ratio around 0.795 .

The validation of results and prediction accuracy performed as suggested by the various researcher that Area Under the Curve (AUC) for excellent (0.90-1.0), very good (0.80-0.90), good (0.70-0.80), average (0.60-0.70), poor (0.50-0.60) (Andualem and Demeke 2019; Naghibi et al. 2015; Parashar et al. 2018; Srivastava 2020). This model of the GWP map has shown AUC 0.726, which indicated good agreement between experimental results and GWP model prediction results.

\section{Conclusions}

This study had performed in a well-planned and systematic manner in a study area located in the semi-arid sub-tropical climatic zone of India. The poor-availability of water is a concern in this projected zone. Further, the availability of freshwater for drinking, agriculture, and other industrial activities is a challenging task in the study area. In this research work, an attempt has been taken to delineate the GWP in the Guna district through geospatial techniques, MCDA, and AHP. The seven types of the thematic-layers (geology, lineament-density, drainage-density, slope, soil, geomorphology, land-use, and land-cover) had used in this research work for the delineation of the GWP zone.

It observed that the $\mathrm{Cl}$ is $\sim 0.0106$, while the $\mathrm{RI}$ for seven variables considered from standard tables is 1.32 . The calculated $\mathrm{CR}$ for this research work was $\sim 0.0080$, much lower than 0.1000 . This low CR indicated moderate consistency in the results of the pair-wise comparisons among the thematic layer assigned weight for the analysis. Hence, the AHP model used in this research work has shown reasonably good accuracy in geospatial prediction of the GWP zone in this study.

The statistical analysis of the GWPI was used in the classification of the study-area into five-zone like very-high, high, moderate, low, and poor groundwater potential zones. The statistics of GWP indicated $\sim 257.67 \mathrm{~km}^{2}(\sim 3.97 \%)$ of study-area possessed excellent conditions, $2404.90 \mathrm{~km}{ }^{2}$ ( 37.09\%) of study-area possessed very good conditions, $\sim 2705.51 \mathrm{~km}^{2}(\sim 41.72 \%)$ of study-area possessed moderate conditions, $\sim 987.73 \mathrm{~km}{ }^{2}$ $(\sim 15.23 \%)$ of study-area possessed poor conditions and $128.83 \mathrm{~km}^{2}(\sim 1.99 \%)$ of study-area possessed very-poor condition.

\section{Declarations}

\section{Acknowledgment}

The author would like to thank the Geological Survey of India (GSI), Central Ground Water Board (CGWB) for providing valuable information. This research work has been partially sponsored by Madhya Pradesh Council of Science and Technology, Bhopal [Research Grant NO/R\&D Project (Physical and Engineering Science)/1203/CST/R\&D/2016]. The author also thanks lab-staff and colleagues for providing valuable assistance during research work. Thanks to all.

\section{Conflict of Interest- None}

\section{References}

1. Adamala S, Rajwade YA, Krishna-Reddy YV (2016) Estimation of crop evapotranspiration using the NDVI vegetation Index. J Appl Nat Sci $8(1): 159-166$ 
2. Andualem TG, Demeke GG (2019) Groundwater potential assessment using GIS and remote sensing: A case study of Guna tana landscape, upper Blue Nile Basin, Ethiopia. Journal of Hydrology Regional Studies 24:1-13

3. Biswas A, Jana A, Sharma S (2012) Delineation of groundwater potential zones using satellite remote sensing and geographic information system techniques: a case study from Ganjam district, Orissa, India. Res J Recent Sci 1(9):59-66

4. CGWB Central Groundwater Board, (2013-20) An annual report published for groundwater of Guna district, India. http://www.cgwb.gov.in/District_Profile/MP/guna.pdf

5. Census of Government of India (2011) The population of the Republic of India

6. Chandio IA, Matori ANB, Wan-Yusof KB, Talpur MAH, Balogun AL, Lawal DU (2013) GIS-based analytic hierarchy process as a multicriteria decision analysis instrument: a review. Arab J Geosci 6(8):3059-3066

7. Chowdhury A, Jha MK, Chowdary VM (2010) Delineation of groundwater recharge zones and identification of artificial recharge sites in West Medinipur District, West Bengal using RS, GIS, and MCDM techniques. Environ Earth Sci 59(6):1209-1222

8. Freeze RA, Cherry JA (1979) Groundwater, 604. Prentice-Hall, Englewood Cliffs

9. Hajkowicz S, Collins K (2007) A review of multiple criteria analysis for water resource planning and management. Water Resour Manag 21(9):1553

10. Hajkowicz S, Higgins A (2008) A comparison of multiple criteria analysis techniques for water resource management. Eur J Oper Res 184(1):255-265

11. Ibrahim-Bathis K, Ahmed SA (2016) Geospatial technology for delineating groundwater potential zones in Doddahalla watershed of Chitradurga district. India. The Egyptian J Remote Sens Space Sci 19(2):223-234

12. IMD Indian Meteorological Department (2011-20) Annual report for Madhya Pradesh published from New Delhi

13. Jha MK, Chowdary VM, Kulkarni Y, Mal BC (2014) Rainwater harvesting planning using geospatial techniques and multicriteria decision analysis. Resour Conserv Recycl 83:96-111

14. Machiwal D, Jha MK, Mal BC (2011) Assessment of groundwater potential in a semi-arid region of India using remote sensing, GIS, and MCDM techniques. Water Resour Manag 25(5):1359-1386

15. Magesh N, Chandrasekar N, Soundranayagam JP (2012) Delineation of groundwater potential zones in the Theni district, Tamil Nadu, using remote sensing, GIS, and MIF techniques. Geosci Front 3(2):189-196

16. Malczewski J (1999) GIS and multicriteria decision analysis. Wiley, New York

17. Mukherjee P, Singh CK, Mukherjee S (2012) Delineation of groundwater potential zones in the arid region of India-a remote sensing and GIS approach. Water Resour Manag 26(9):2643-2672

18. Murasingh S, Jha R, Adamala S (2018) The geospatial technique for delineation of groundwater potential zone in mine and dense forest area using a weighted index overlay technique, Groundwater, and Sustainable Development. https://doi.org/10.1016/j.gsd.2017.12.001

19. Murthy KSR, Mamo AG (2009) Multi-criteria decision evaluation in groundwater zones identification in Moyale Teltele subbasin, South Ethiopia. Int J Remote Sens 30(11):2729-2740

20. Naghibi SA, Pourghasemi HR, Dixon B (2016) GIS-based groundwater potential mapping using boosted regression tree, classification and regression tree, and random forest machine learning models in Iran. Environ Monit Assess 188(1):44

21. Naghibi SA, Pourghasemi HR, Pourtaghi ZS, Rezaei A (2015) Groundwater qanat potential mapping using frequency ratio and Shannon's entropy models in the Moghan watershed. Iran Earth Sci Inform 1(8):171-186

22. Nampak H, Pradhan B, Manap MA (2014) Application of GIS-based data-driven evidential belief function model to predict groundwater potential zonation. J Hydrol 513:283-300

23. Parashar SK, Srivastava SK, Dutta NN, Garlapati VK (2018) Engineering aspects of immobilized lipases on esterification: A special emphasis on crowding, confinement, and Diffusion effects. Engineering in Life Science 18:308-316

24. Pourghasemi HR, Mohammady M, Pradhan B (2012) Landslide susceptibility mapping using the index of entropy and conditional probability models in GIS: safarood Basin. Iran Catena 97:71-84

25. Prasad MBK, Ramanathan AL, Srivastava SK, Anshumali, Saxena R (2006) Metal fractionation studies in Surfacial and Core sediments in the Achankovil River basin, India. Environmental Monitoring Assessment 121:77-102

26. Rahmati O, Samani AN, Mahdavi M, Pourghasemi HR, Zeinivand H (2015) Groundwater potential mapping at the Kurdistan region of Iran using the analytic hierarchy process and GIS. Arab J Geosci 8(9):7059-7071

27. Rajaveni SP, Brindha K, Elango L (2017) Geological and geomorphological controls on groundwater occurrence in a hard rock region. Appl Water Sci 7(3):1377-1389

28. Ranjan R, Srivastava SK, Ramanathan AL (2017) An assessment of hydrogeochemistry of two wetlands located in Bihar State in the subtropical climatic zone of India. Environmental Earth Sciences 76(1):1-19

29. Saaty TL (1990) Decision making for leaders: the analytic hierarchy process for decisions in a complex world. RWS publications 
30. Sahoo S, Jha MK, Kumar N, Chowdary VM (2015) Evaluation of GIS-based multicriteria decision analysis and probabilistic modeling for exploring groundwater prospects. Environ Earth Sci 74(3):2223-2246

31. Senanayake I, Dissanayake D, Mayadunna B, Weerasekera W (2016) An approach to delineate groundwater recharge potential sites in Ambalantota, Sri Lanka using GIS techniques. Geoscience Frontiers 7(1):115-124

32. Shiklomanov LA (1993) World Freshwater Resources. In: Gleick PH (ed) Water in Crisis: A Guide to World's Freshwater Resources. Oxford University Press, New York, pp 13-24

33. Singh CK, Shashtri S, Singh A, Mukherjee S (2011) Quantitative modeling of groundwater in the Satluj River basin of Rupnagar district of Punjab using remote sensing and geographic information system. Environ Earth Sci 62:871-881

34. Singh SK, Zeddies M, Shankar U, Griffiths GA (2019) Potential groundwater recharges zones within New Zealand. Geosci Front 10:1065-1072

35. Srivastava SK (2019) Assessment of groundwater quality for the suitability of irrigation and its impacts on crop yields in the Guna district, India. Agrc Water Manage 216:224-241. https://doi.org/10.1016/j.agwat.2019.02.005

36. Srivastava SK (2020) Advancement in biogas production from solid waste by optimizing anaerobic digestion. Waste Disposal Sustainable Energy 2:85-102. https://doi.org/10.1007/s42768-020-00036-x

37. Srivastava SK, Ramanathan AL (2008) Geochemical assessment of groundwater quality in vicinity Bhalswa Landfill, Delhi, India by using graphical and multivariate statistical methods. Journal of Environmental Geology 53:1509-1528

38. Srivastava SK, Ramanathan AL (2018a) Geochemical assessment of fluoride enrichment and nitrate contamination in groundwater in hard rock aquifer by using graphical and statistical methods. J Earth Syst Sci 127(7):104 (1-23)

39. Srivastava SK, Ramanathan AL (2018b) Assessment of landfills vulnerability on the groundwater quality located near flood-plain of the Perennial River and simulation of contaminant transport. Modeling Earth System Environment 4(2):729-752

40. Thapa R, Gupta S, Guin S, Kaur H (2018) Sensitivity analysis and mapping of the potential groundwater vulnerability zones in Birbhum district, India: A comparative approach between vulnerability models. Water Science 32:44-66

41. Thorpe HR, Scott DM (1999) An evaluation of four soil moisture models for estimating natural groundwater recharge. J Hydrol 38(2):179-209

42. Todd DK (1980) Groundwater hydrology, 2nd edn. Wiley, New York

43. Vijith H (2007) Groundwater potential in the hard rock terrain of Western-Ghat-A case study from Kottayam, district, Kerala using resource sat (IRS-P6) data and GIS techniques. J Indian Soc Remote Sens 35(2):171-179

44. Wada Y, Van-Beek LPH, Van-Kempen CM, Reckman JWT, Vasak S, Bierkens MFP (2010) Global depletion of groundwater resources. Geophysical Research Letter 37L20402:1-5.

45. White PA, Hong YS, Murray DL, Scott DM, Thorpe HR (2003) Evaluation of regional models of rainfall recharge to the subsurface water by comparison with lysimeter measurements, Canterbury, New Zealand. J Hydrol 42(1):39-64

46. Workineh H, Dejene H, lyasu G, Thomas K, Shimelis A, Getachew B, Mohamed E (2010) Geology, Geochemistry, and Gravity Survey of the Debre Tabor Area. Geological Survey of Ethiopia, Addis Ababa

47. Yeh HF, Cheng YS, Lin HI, Lee CH (2016) Mapping of groundwater recharge potential zone using a GIS approach in the Hualian River. Taiwan Sust Environ Res 26(1):33-43

\section{Figures}


STUDY AREA

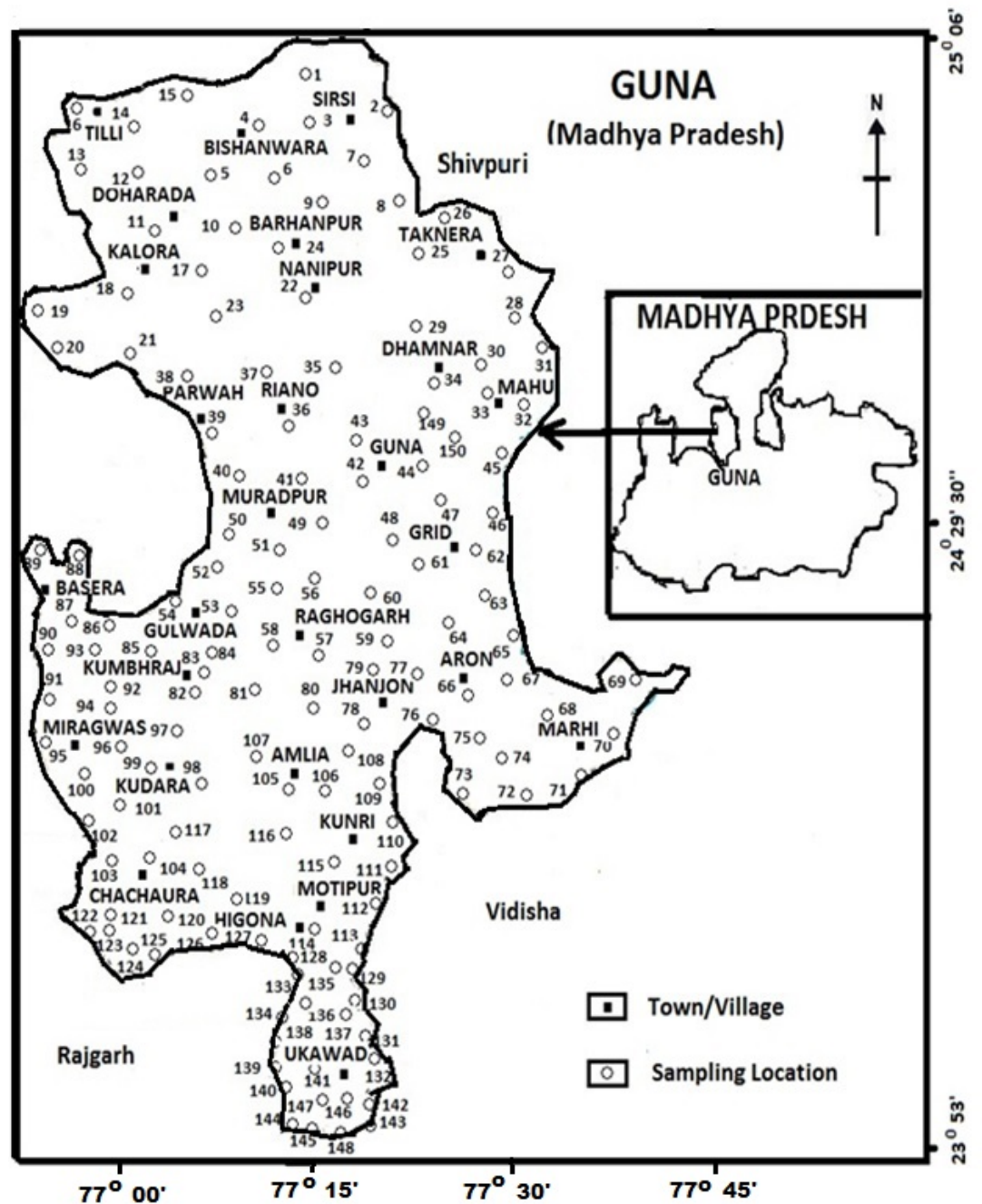

Figure 1

Study Area Note: The designations employed and the presentation of the material on this map do not imply the expression of any opinion whatsoever on the part of Research Square concerning the legal status of any country, territory, city or area or of its authorities, or concerning the delimitation of its frontiers or boundaries. This map has been provided by the authors. 


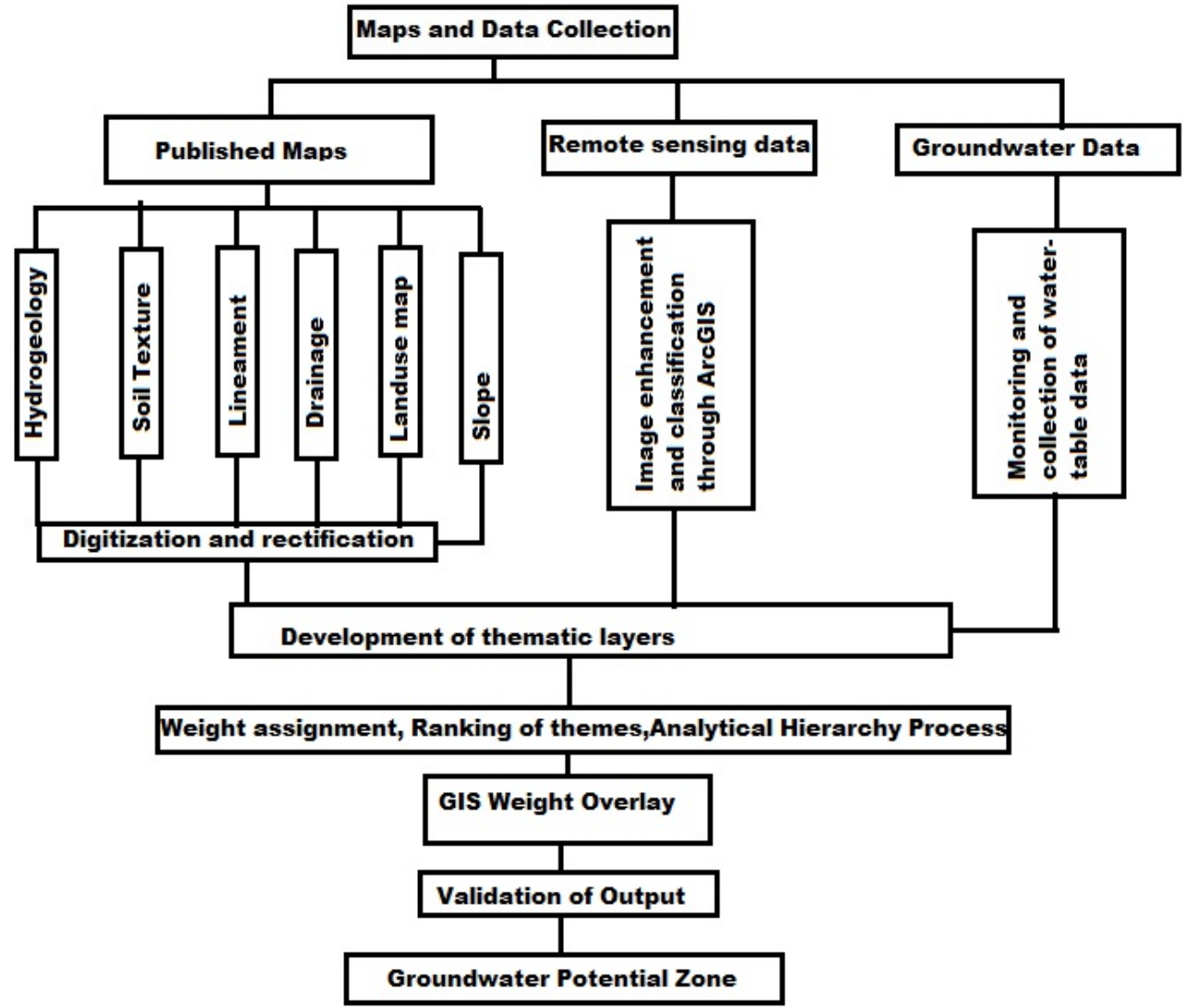

Figure 2

The summary of deleniation of GWP in the Guna district 


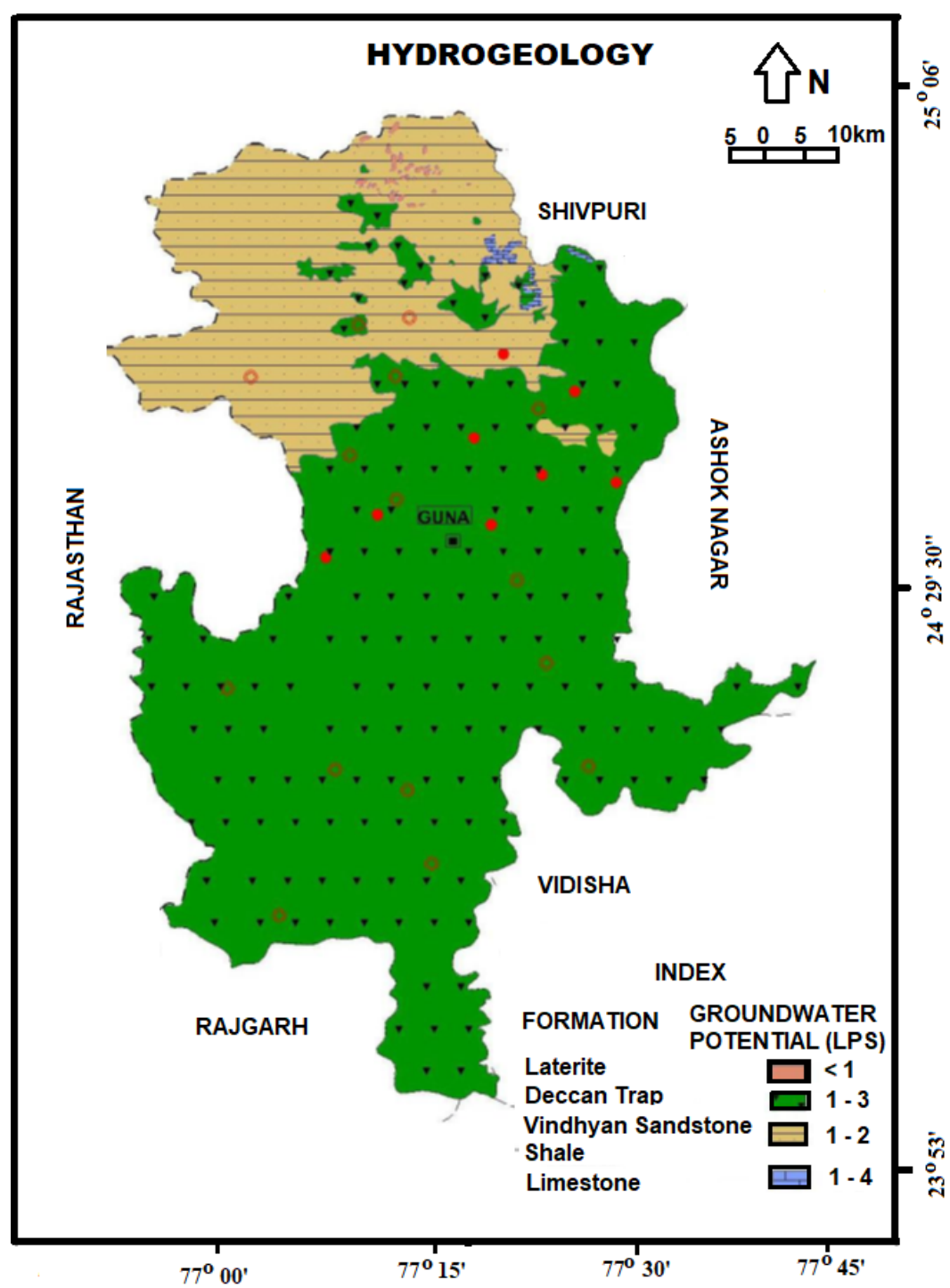

Figure 3

Hydrogeology map Note: The designations employed and the presentation of the material on this map do not imply the expression of any opinion whatsoever on the part of Research Square concerning the legal status of any country, territory, city or area or of its authorities, or concerning the delimitation of its frontiers or boundaries. This map has been provided by the authors. 


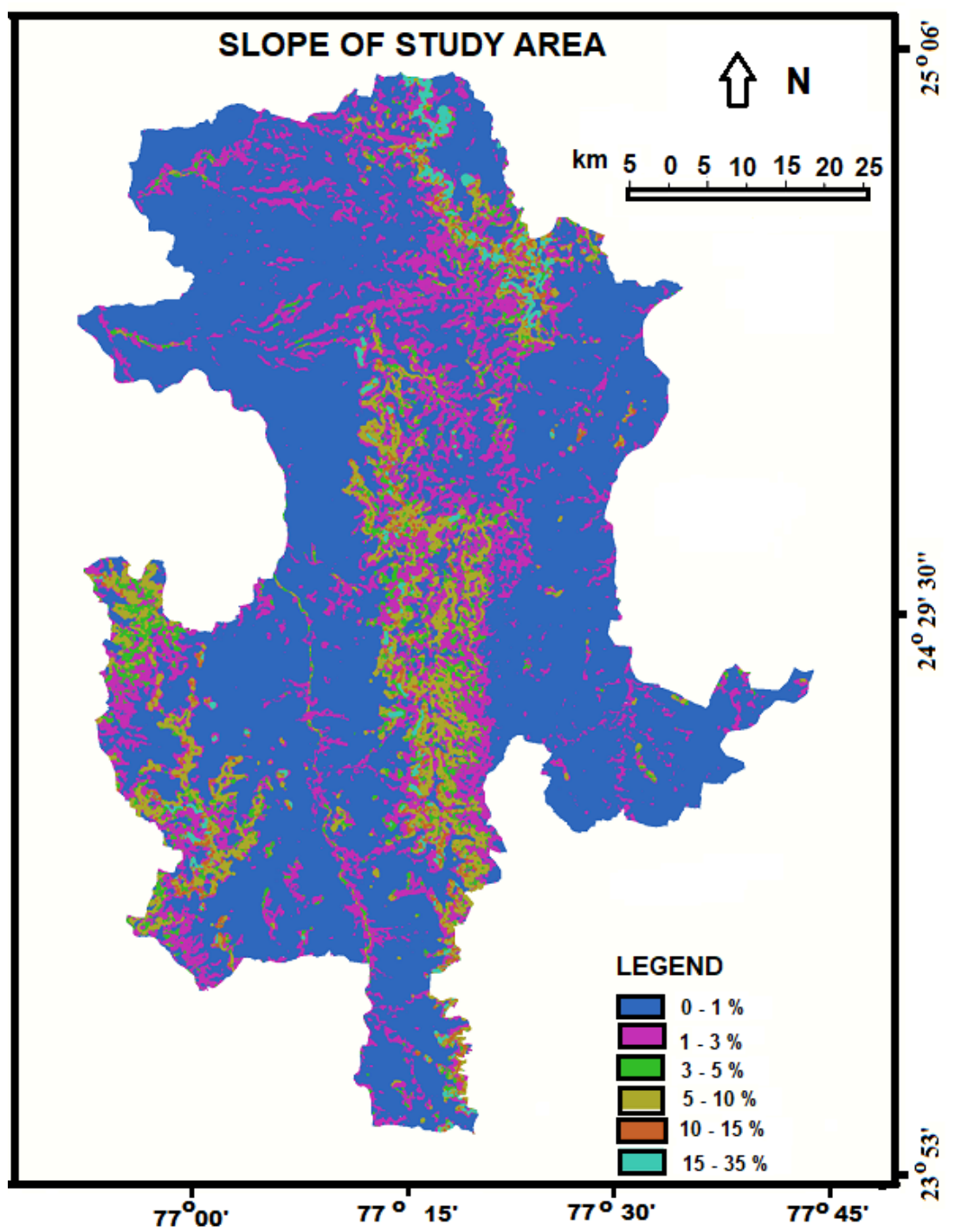

Figure 4

Slope of the topography Note: The designations employed and the presentation of the material on this map do not imply the expression of any opinion whatsoever on the part of Research Square concerning the legal status of any country, territory, city or area or of its authorities, or concerning the delimitation of its frontiers or boundaries. This map has been provided by the authors. 


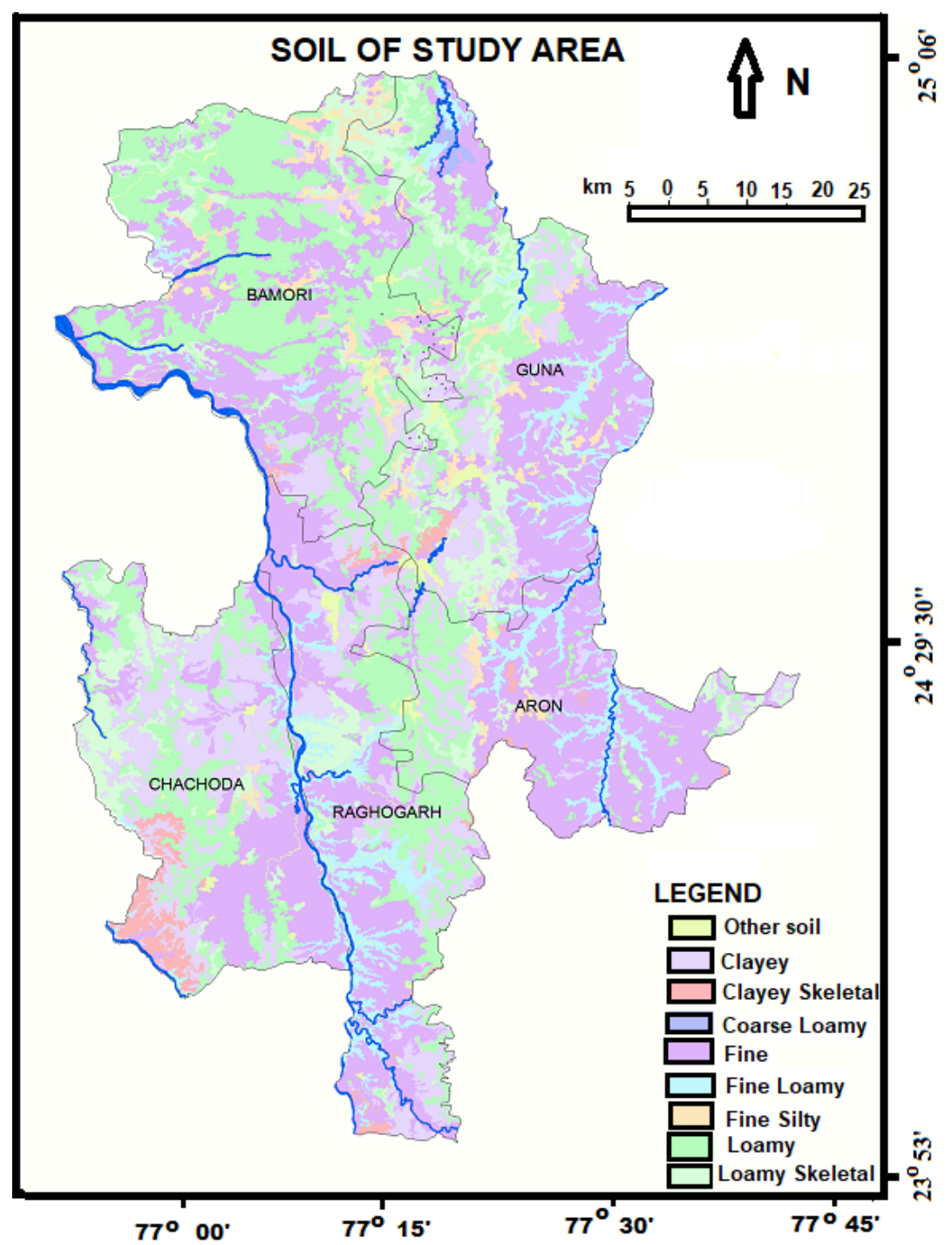

Figure 5

Soils map Note: The designations employed and the presentation of the material on this map do not imply the expression of any opinion whatsoever on the part of Research Square concerning the legal status of any country, territory, city or area or of its authorities, or concerning the delimitation of its frontiers or boundaries. This map has been provided by the authors. 


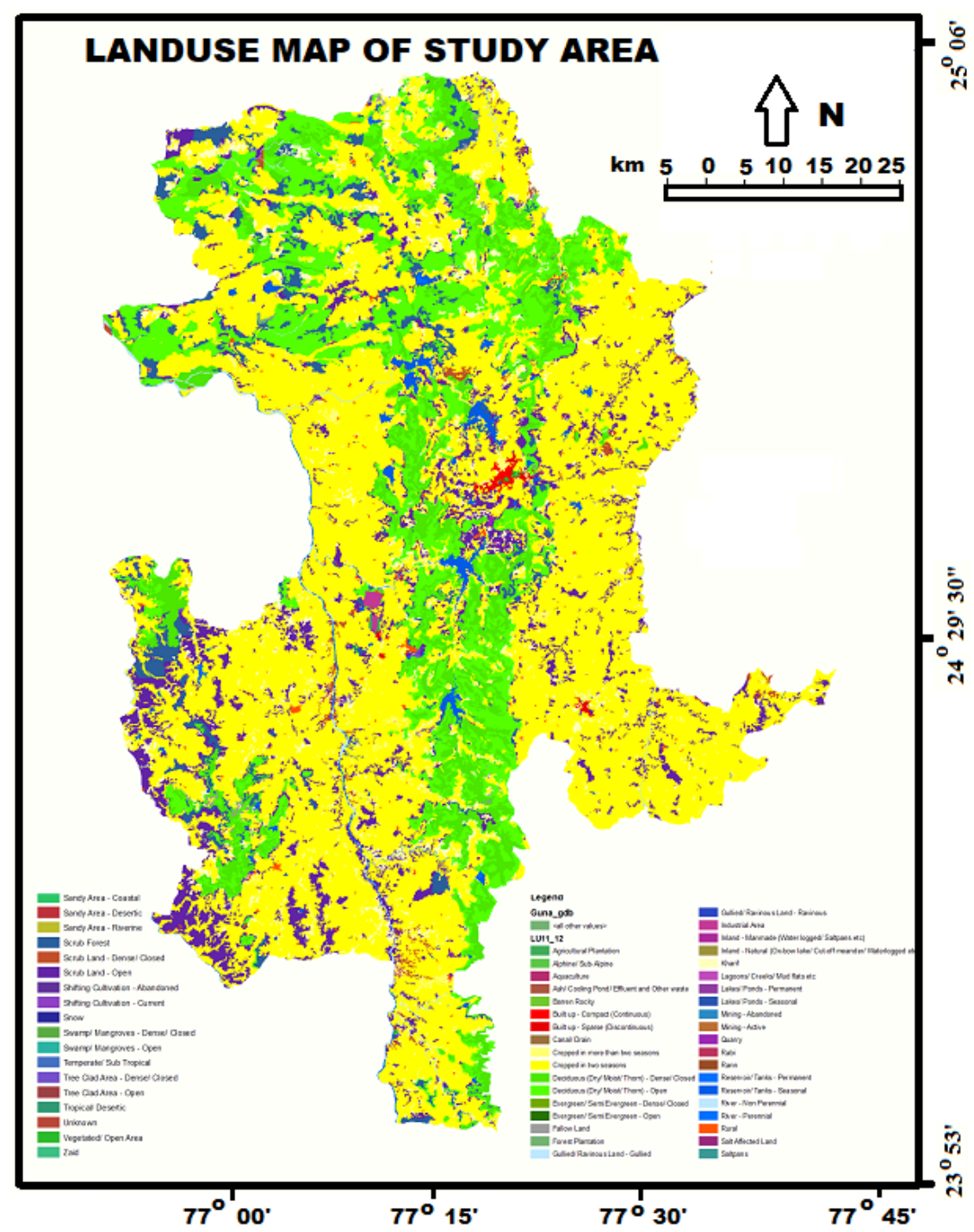

Figure 6

Land-use map Note: The designations employed and the presentation of the material on this map do not imply the expression of any opinion whatsoever on the part of Research Square concerning the legal status of any country, territory, city or area or of its authorities, or concerning the delimitation of its frontiers or boundaries. This map has been provided by the authors. 


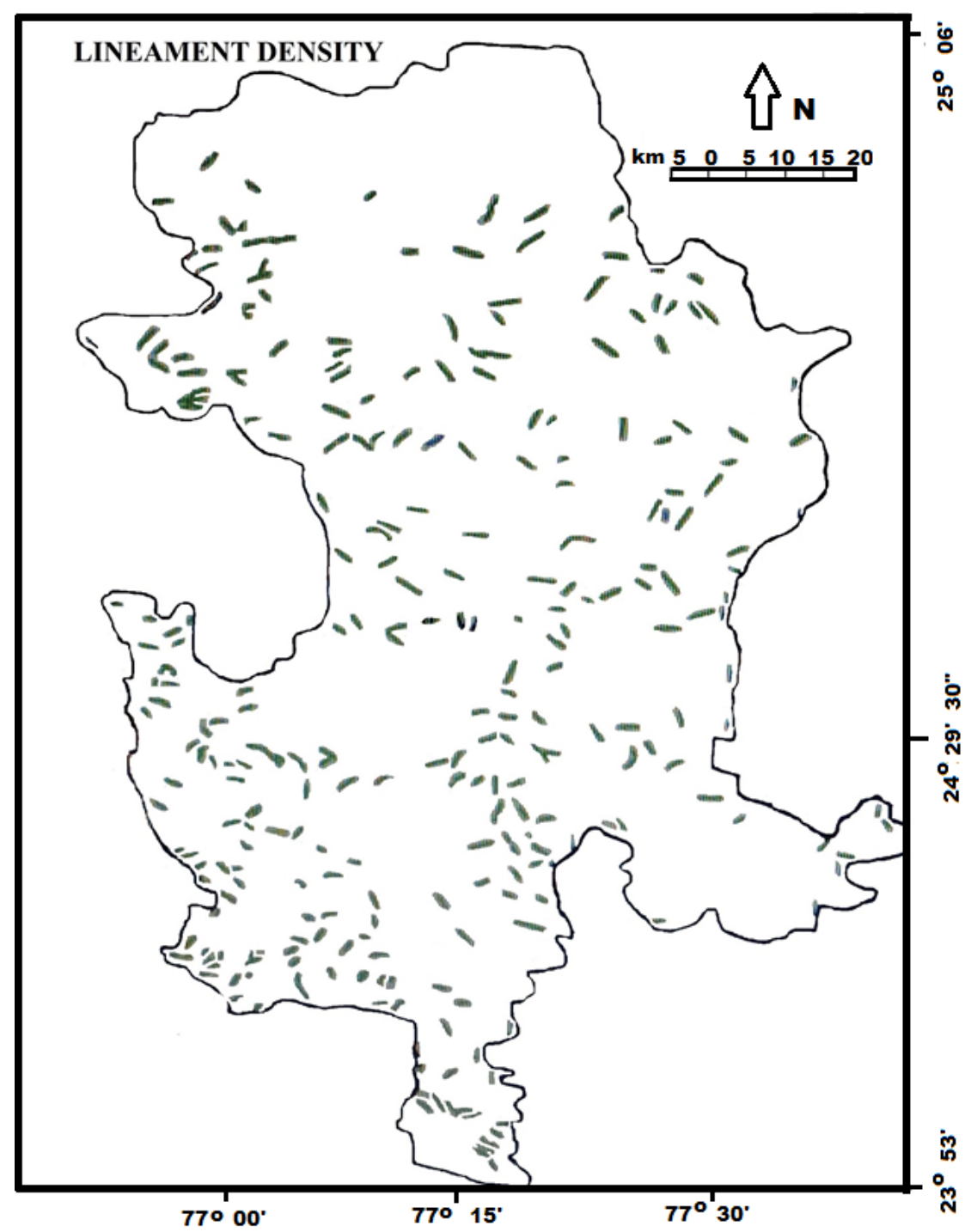

Figure 7

Lineament density map Note: The designations employed and the presentation of the material on this map do not imply the expression of any opinion whatsoever on the part of Research Square concerning the legal status of any country, territory, city or area or of its authorities, or concerning the delimitation of its frontiers or boundaries. This map has been provided by the authors. 


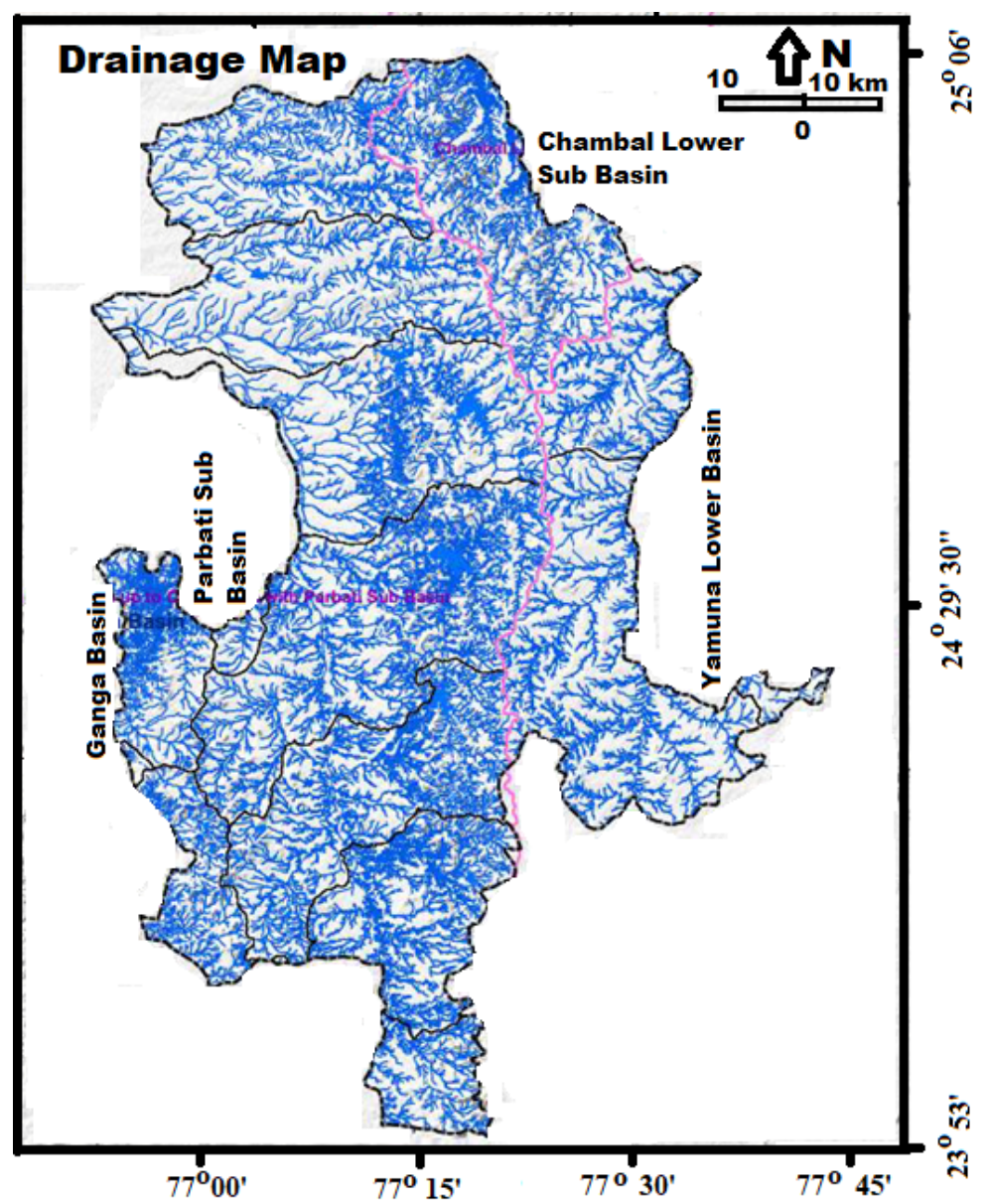

Figure 8

Drainage density map Note: The designations employed and the presentation of the material on this map do not imply the expression of any opinion whatsoever on the part of Research Square concerning the legal status of any country, territory, city or area or of its authorities, or concerning the delimitation of its frontiers or boundaries. This map has been provided by the authors. 


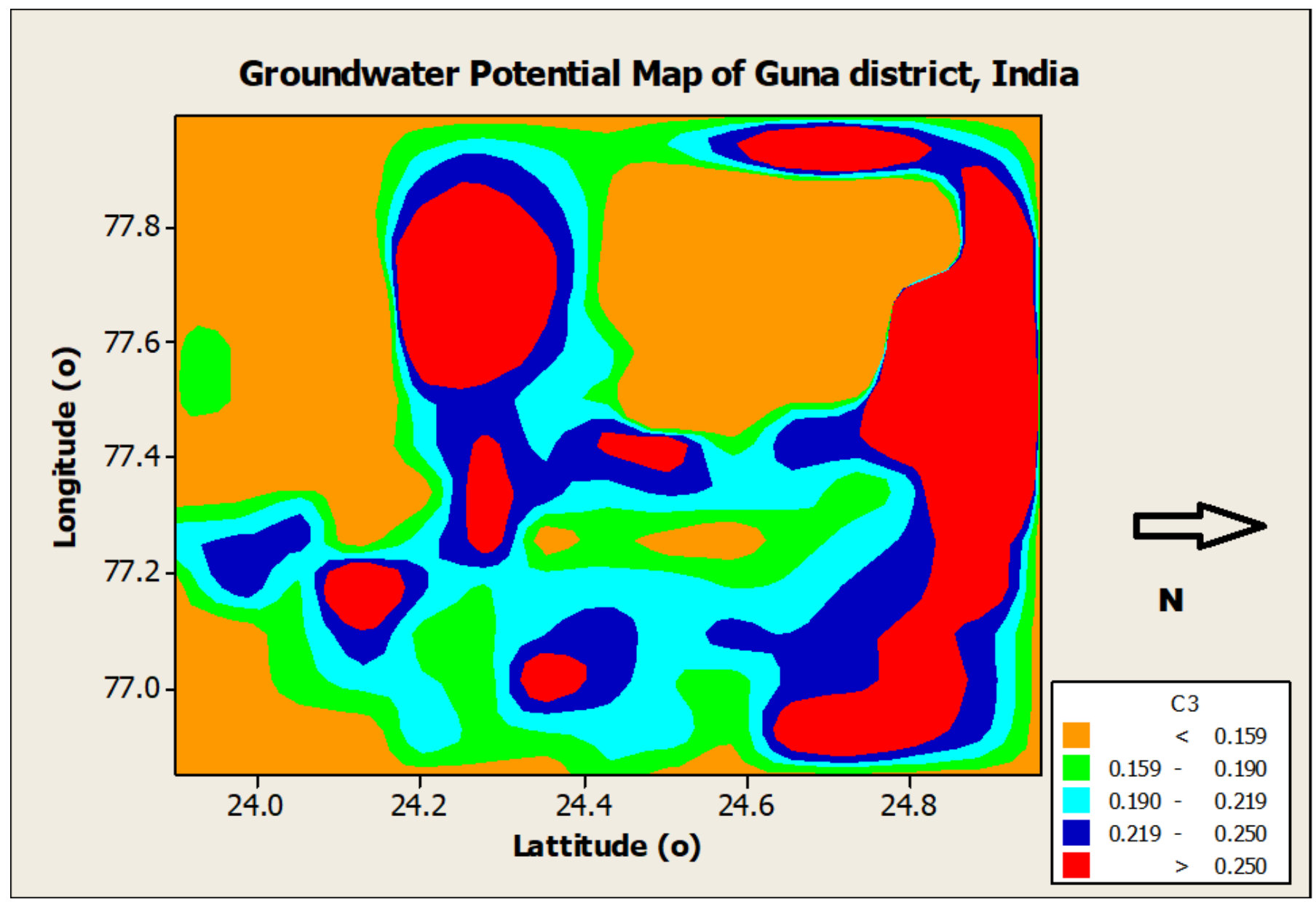

Figure 9

Groundwater Potential map of Guna district Note: The designations employed and the presentation of the material on this map do not imply the expression of any opinion whatsoever on the part of Research Square concerning the legal status of any country, territory, city or area or of its authorities, or concerning the delimitation of its frontiers or boundaries. This map has been provided by the authors.

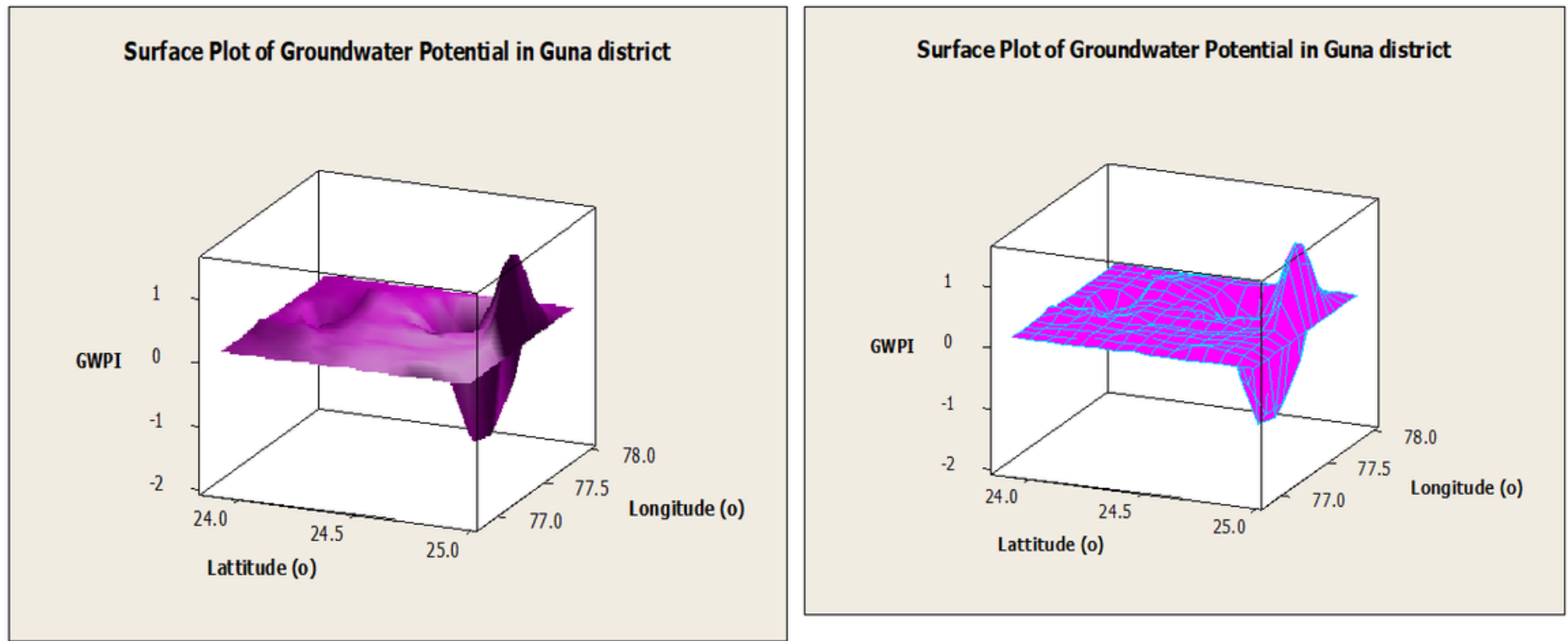

Figure 10

a Surface plot of the GWP in Guna district b Surface plot of GWP in Guna district 


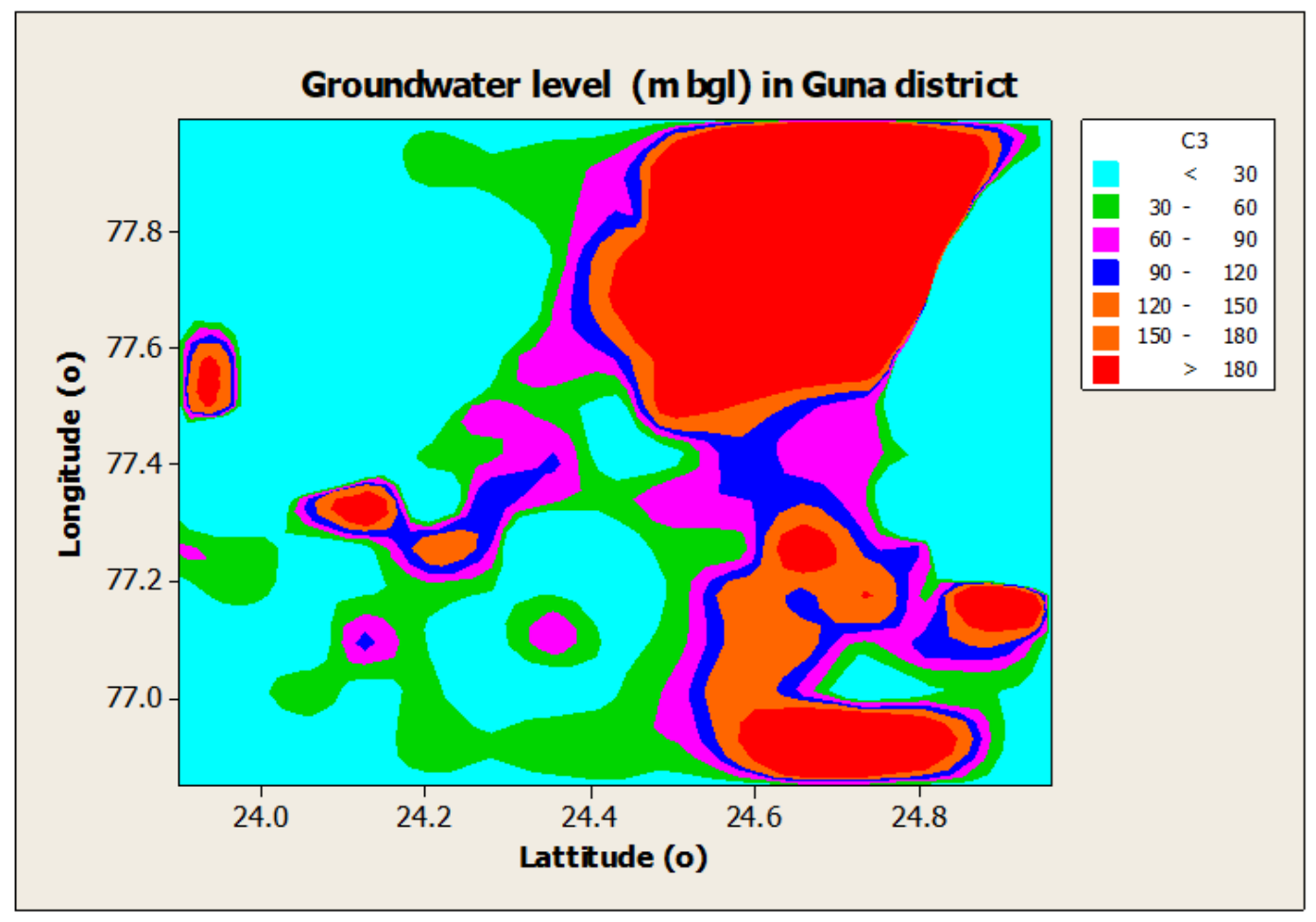

Figure 11

Groundwater level in study area Note: The designations employed and the presentation of the material on this map do not imply the expression of any opinion whatsoever on the part of Research Square concerning the legal status of any country, territory, city or area or of its authorities, or concerning the delimitation of its frontiers or boundaries. This map has been provided by the authors.

ROC Curve Analysis

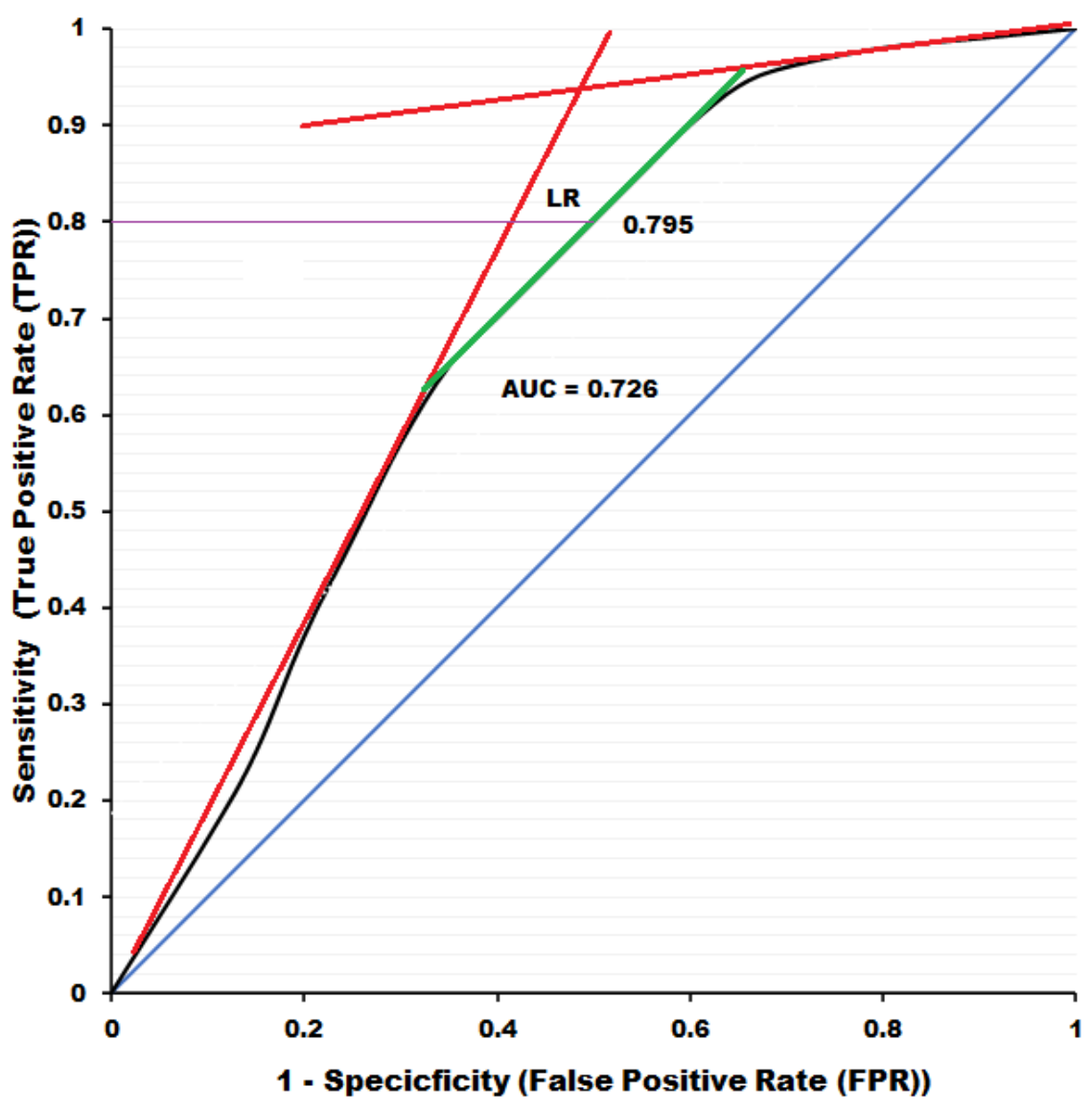


Figure 12

ROC Curve

Page 25/25 